\title{
On the Issue of Noble Metals in the DWPF Melter
}

Nick D. Hutson

Doug C. Witt

Dennis F. Bickford

Savannah River Technology Center, Aiken, SC

S. K. Sundaram

Pacific Northwest National Laboratory, Richland, WA

August 31, 2001 
This document was prepared in conjunction with work accomplished under Contract No.

DE-AC09-96SR18500 with the U.S. Department of Energy.

\section{DISCLAIMER}

This report was prepared as an account of work sponsored by an agency of the United States Government. Neither the United States Government nor any agency thereof, nor any of their employees, makes any warranty, express or implied, or assumes any legal liability or responsibility for the accuracy, completeness, or usefulness of any information, apparatus, product or process disclosed, or represents that its use would not infringe privately owned rights. Reference herein to any specific commercial product, process or service by trade name, trademark, manufacturer, or otherwise does not necessarily constitute or imply its endorsement, recommendation, or favoring by the United States Government or any agency

thereof. The views and opinions of authors expressed herein do not necessarily state or reflect those of the United States Government or any agency thereof.

This report has been reproduced directly from the best available copy.

Available for sale to the public, in paper, from: U.S. Department of Commerce, National Technical Information Service, 5285 Port Royal Road, Springfield, VA 22161, phone: (800)

553-6847, fax: (703) 605-6900, email: orders@ntis.fedworld.gov online ordering: http://www.ntis.gov/ordering.htm

Available electronically at http://www.doe.gov/bridge

Available for a processing fee to U.S. Department of Energy and its contractors, in paper, from: U.S. Department of Energy, Office of Scientific and Technical Information, P.O. Box 62, Oak Ridge, TN 37831-0062, phone: (865 ) 576-8401, fax: (865) 576-5728, email: reports@ adonis.osti.gov 


\section{Table of Contents}

Table of Contents .....................................................................................................................

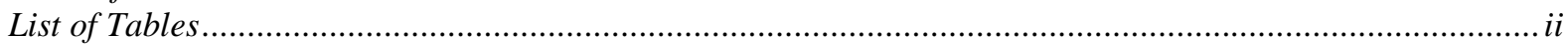

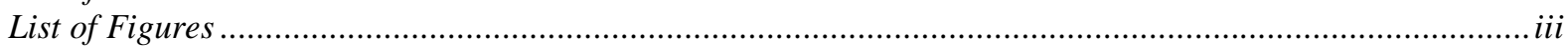

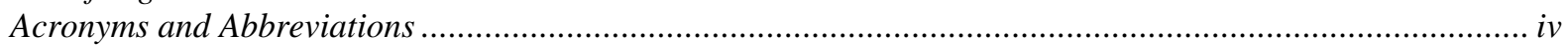

1.0 SUMMARY AND RECOMMENDATIONS FOR DWPF ....................................................................1

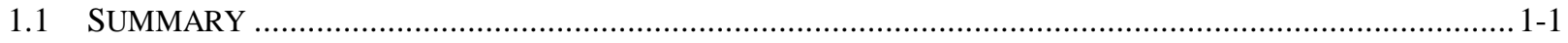

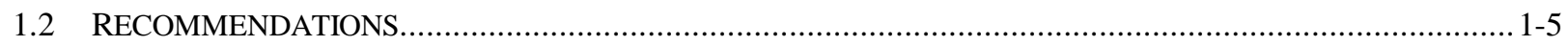

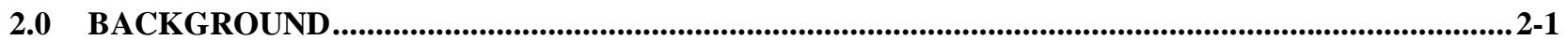

3.0 NOBLE METALS TESTING IN THE INTEGRATED DWPF MELTER SYSTEM (IDMS)...............3-1

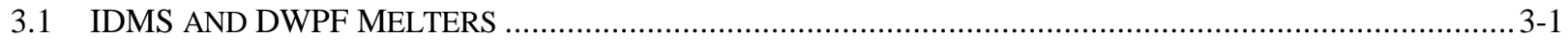

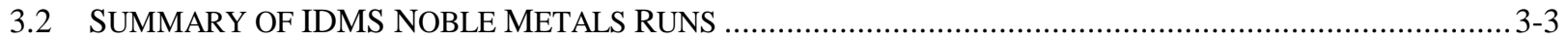

3.3 BEHAVIOR OF THE NOBLE METALS..................................................................................

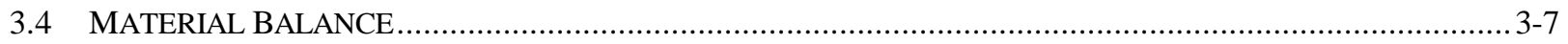

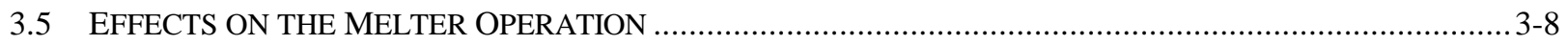

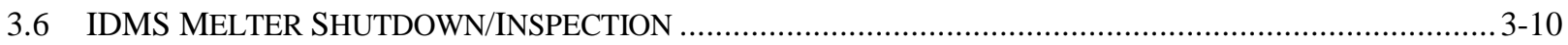

4.0 MELTER CORE SAMPLES AND FLOOR DEPOSITS .................................................................4-1

4.1 FLOOR SAMPLES TAKEN DURING OPERATION .................................................................

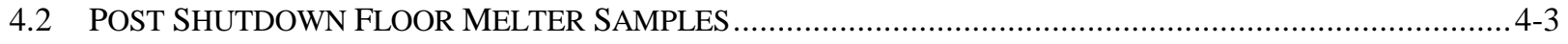

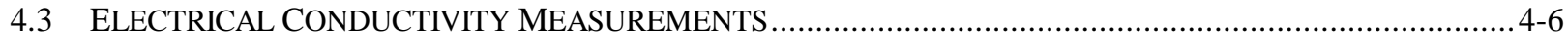

5.0 NOBLE METALS TESTING IN THE PNNL ENGINEERING SCALE MELTER (ESM) ..................5-1

6.0 WEST VALLEY DEMONSTRATION PROJECT OPERATING EXPERIENCE ...............................6-1

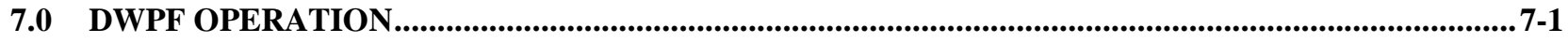

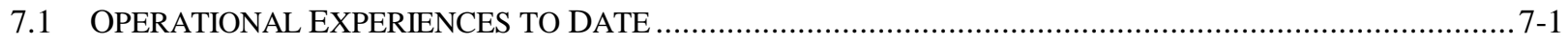

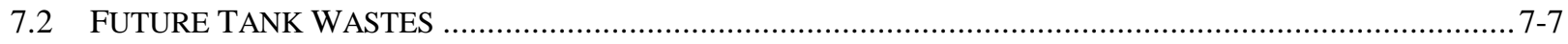

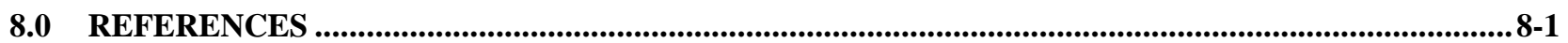




\section{List of Tables}

1-1 Predicted and Measured Noble Metal Concentrations in Various Savannah River Sludges ..............................1-1

2-1. Noble Metals in German, Japanese, and American Waste Glasses................................................................2-2

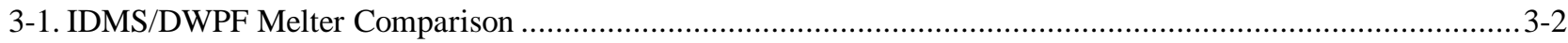

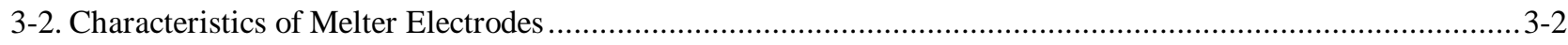

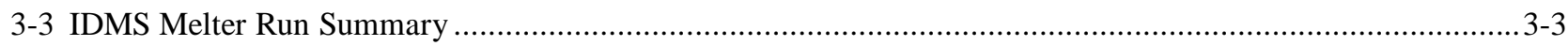

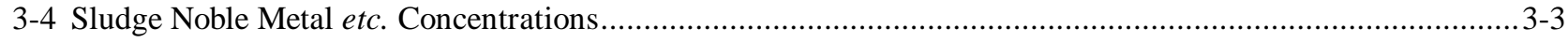

3-5 Estimated Retention of Noble Metals in IDMS Melter......................................................................... $3-5$

4-1 Analysis of IDMS Melter Floor Samples Taken during Operation from the Feed Tube Port .......................... 4-2

4-2 Analysis of IDMS Melter Floor Samples Taken during Operation from the Borescope Port............................4-3

4-3 Wt-\% Concentration of Spinel and Nobel Metals (Ru, Rh, and Pd) from IDMS Floor Samples ...................... 4-5

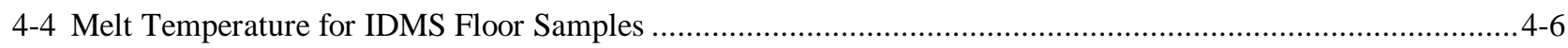

4-5 Conductivity / Resistance of IDMS Melter Floor Samples …................................................................. $4-7$

4-6 Fitting Parameters for Relationship between Resistance and Temperature ….............................................. 4-8

5-1 Selected Components in Floor Samples from the Engineering Scale Melter (ESM) …................................5-2

7-1 Monthly Average Operational Parameters for the DWPF Melter ........................................................... $7-5$

7-2 Predicted and Measured Noble Metal Concentrations in Various Savannah River Sludges ............................7-6 


\section{List of Figures}

1-1 Monthly Average Upper-to-Lower Resistance Ratio for the DWPF Melter ................................................... 1-2

1-2 Monthly Average Upper and Lower Glass Pool Resistances .................................................................. 1-3

3-1 Ruthenium Settling during Periods of Idling in the IDMS Melter............................................................ 3-7

4.1 SEM Micrograph of IDMS Melter Floor Sample (BLOB-10) ….............................................................. $4-5$

4-2 Resistance (ohms) versus Temperature $\left({ }^{\circ} \mathrm{C}\right)$ for IDMS melter floor samples ............................................... 4-8

4-3 Resistance (ohms) versus Temperature $\left({ }^{\circ} \mathrm{C}\right)$ for IDMS melter floor samples ................................................ 4-9

4-4 Relationship between Noble Metal Content ([NM], wt-\%) and the Measured Resistance (ohms) at $1150{ }^{\circ} \mathrm{C}$ for IDMS Melter Floor (BLOB) Samples................................................................................................. $4-9$

4-5 Relationship between Noble Metal Content ([NM], wt-\%) and the Measured Conductivity (S/m) at 1150

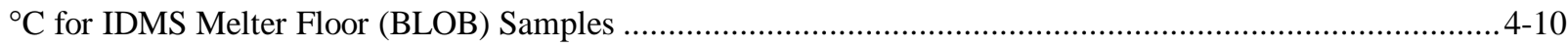

5-1 Overhead Schematic of Engineering Scale Melter (ESM) .......................................................................... $5-1$

7-1 Monthly Average Upper-to-Lower Resistance Ratio - DWPF Melter ........................................................... 7-1

7-2 Monthly Average Upper and Lower Glass Pool Resistances .................................................................. 7-2

7-3 Monthly Average Glass Temperature Ratio (Upper-to-Lower) .................................................................. 7-3

7-4 Monthly Upper and Lower Electrode Current (amps) ............................................................................ $7-3$

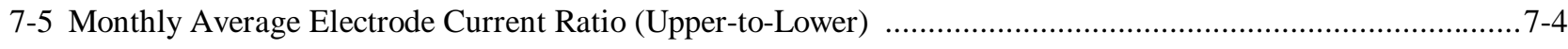




\section{Acronyms and Abbreviations}

CETL: Clemson Environmental Technologies Laboratory

DWPF: Defense Waste Processing Facility

EDAX: $\quad$ Energy Dispersive Analysis by X-Ray

ESM: $\quad$ Engineering Scale Melter

HEWC: $\quad$ High Enrichment Waste Concentrate

HWVP1: First Run of the HWVP Process Demonstration

HWVP2: $\quad$ Second Run of the HWVP Process Demonstration

HWVP: $\quad$ The former Hanford Waste Vitrification Plant Project

IDMS: $\quad$ Integrated DWPF Melter System

INE/KfK: Institute für Nuklear Entsorgungstechnik at Kernforshungzentrum

Karlsruhe (Nuclear Fuel Cycle Center)

LEWC: Low Enrichment Waste Concentrate

NCAW: $\quad$ Neutralized Current Acid Waste

PNNL: $\quad$ Pacific Northwest National Laboratory

RSM: $\quad$ Research Scale Melter (at PNNL)

SEM: $\quad$ Scanning Electron Microscopy/Microscope

SRS: $\quad$ Savannah River Site

SRTC: $\quad$ Savannah River Technology Center

TVF: $\quad$ Tokai Vitrification Facility (Japan)

WAK: Waste from the Karlsruhe Reprocessing Plant

WSRC: $\quad$ Westinghouse Savannah River Company

WVDP: West Valley Demonstration Project

XRD: $\quad$ X-Ray Diffraction 


\subsection{Summary and Recommendations for DWPF}

\subsection{Summary}

Caveat: This report presents some historical data from the radioactive operation of the DWPF melter. Some of the data seem to indication that the melter is displaying symptoms that may be linked to accumulation of noble metals or other conductive material on the melter floor. However, one must be very careful when interpreting the data. The complex and often competing effects of waste composition, glass pool temperatures, and operating conditions must also be considered. A more detailed evaluation of the DWPF melter data is recommended. Full involvement of DWPF melter engineers and technical personnel is vital to this evaluation.

The fission-product noble metals $(\mathrm{Ru}, \mathrm{Rh}$, and $\mathrm{Pd})$, their alloys and compounds tend to settle to the floor of Jouleheated ceramic melters that are used for High Level Waste (HLW) vitrification. An accumulation of these dense, conductive and highly viscous materials can adversely affect the melter operation by decreasing the power release and distribution in the bulk glass in the melter. This can decrease the feed throughput capacity and diminish the melter's ability to maintain the desired operating temperature. This conductive layer can also cause non-uniform and uncontrollable current distributions at the surface of the electrodes that can lead to physical damage or failure of the electrodes.

The DWPF has been in radioactive operation since 1996 and will soon begin feeding a new sludge with concentrations of noble metals that are higher than have been processed to date. Table 1-1 gives the predicted noble metal concentrations for HM, PUREX and Blend sludges (a hypothetical blending of PUREX and HM). Also listed are measured values for Tank 51 (sludge batch 1A, macrobatch 1), and for Tank 40, the next sludge batch to the DWPF. The values for Tank 40 represent the maximum (overwashed) and minimum (as received) bounding values for these components (Fellinger and Bibler, 2001). The values for Tank 40 indicate a significant increase in the expected values of $\mathrm{Ru}$ and $\mathrm{Rh}$ (the noble metals that tend to be retained in the melter in the highest percentages) over that of Tank 51.

Table 1-1. Predicted and Measured Noble Metal Concentrations in Various Savannah River Sludges

\begin{tabular}{ccccccc}
\hline & $\begin{array}{c}\text { Blend } \\
\text { Predicted } \\
\text { wt-\% }\end{array}$ & $\begin{array}{c}\text { HM } \\
\text { Predicted } \\
\text { wt-\% }\end{array}$ & $\begin{array}{c}\text { PUREX } \\
\text { Predicted } \\
\text { wt-\% }\end{array}$ & $\begin{array}{c}\text { Tank 51 } \\
\text { Measured } \\
\text { wt-\% }\end{array}$ & $\begin{array}{c}\text { Tank 40 Measured } \\
\text { (as received) } \\
\text { wt-\% }\end{array}$ & $\begin{array}{c}\text { (overwashed) } \\
\text { wt-\% }\end{array}$ \\
\hline $\mathrm{Ru}$ & 0.100 & 0.217 & 0.028 & 0.007 & 0.019 & 0.042 \\
$\mathrm{Rh}$ & 0.018 & 0.038 & 0.008 & 0.001 & 0.005 & 0.010 \\
$\mathrm{Pd}$ & 0.045 & 0.079 & 0.026 & 0.006 & 0.001 & 0.001 \\
$\mathrm{Ag}$ & 0.014 & 0.014 & 0.014 & 0.014 & 0.007 & 0.015 \\
\hline
\end{tabular}

(wt-\% of the total sludge solids, soluble and insoluble) 
The ratio of upper-to-lower melt resistances was used during the operation of the Integrated DWPF Melter System (IDMS) as an indication of noble metal accumulation. During the time period from July 2000 to December 2000, the monthly average ratio of upper-to-lower melt apparent resistance increased from 1.02 to 1.60 . This is shown in Figure 1-1.

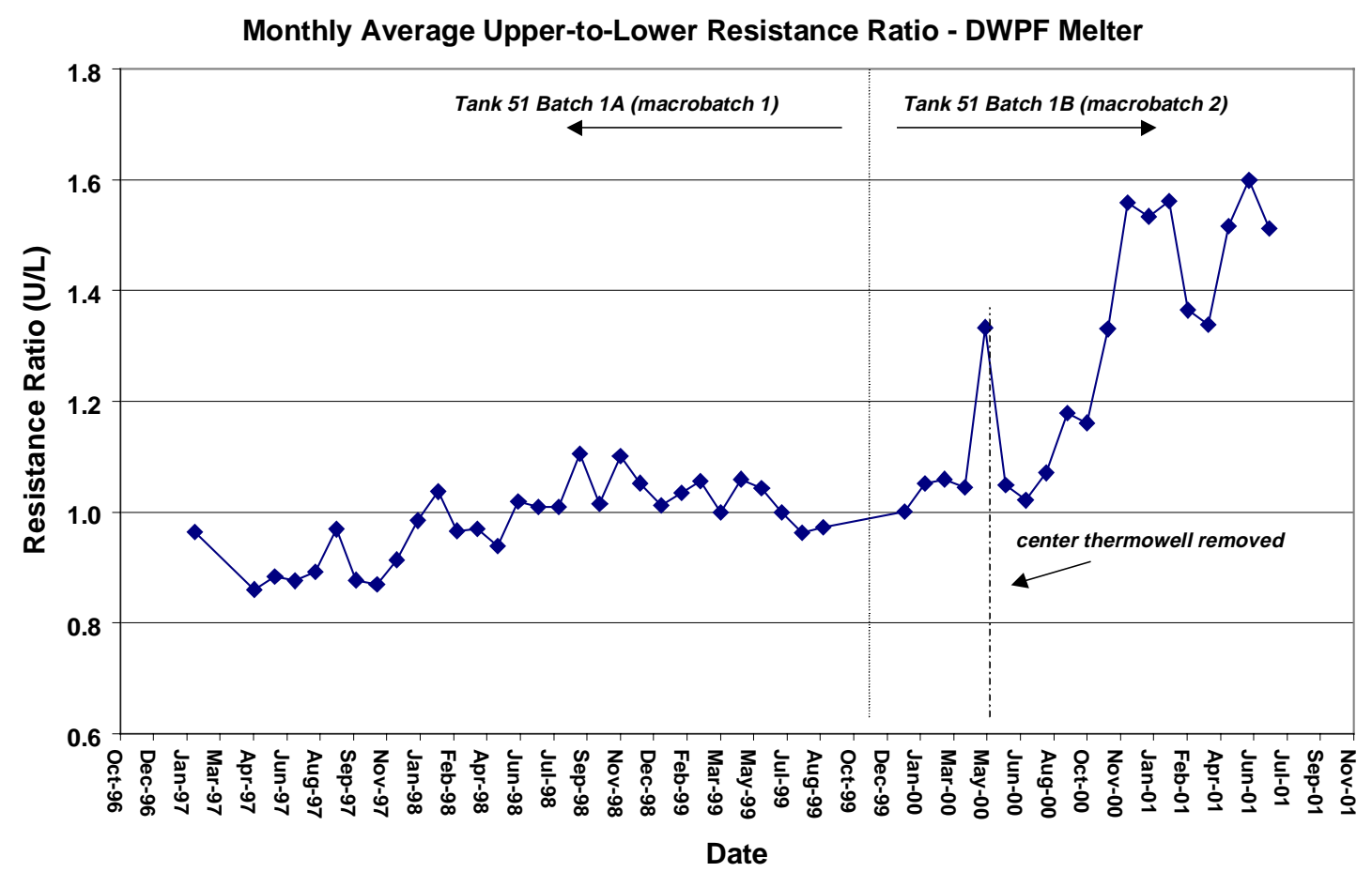

Figure 1-1. Monthly Average Upper-to-Lower Resistance Ratio for the DWPF Melter

There are operational changes, however, that must be considered in evaluating this data. In November 1999, a new sludge macrobatch (Tank 51 sludge 1B, macrobatch 2) was introduced. This sludge was higher in aluminum than the previous macrobatch had been. This resulted in a more viscous molten glass and possibly less convection in the melter. Also, in May 2000 a thermowell with three thermocouples was removed from the center of the melter (measuring the lower glass pool temperature). The average lower glass pool temperature abruptly dropped at that time since it was then the average of only three thermocouple readings in a thermowell located near the outer edge of the melter wall (a colder region of the melt pool). So, the change in the resistance ratio is, at least partially, due to this artificial drop in the lower glass temperature (and a corresponding increase in the upper glass temperature). Prior to May 2000, the average lower glass pool temperature, which at that time was an average of six thermocouple readings (three in the center of the melter and three at the outer edge of the melt pool), consistently ran from 1100 to $1120^{\circ} \mathrm{C}$. The average upper glass pool temperature was typically between 1140 and $1170{ }^{\circ} \mathrm{C}$. However, after May 2000 , the monthly average temperature (of just the three outer edge thermocouple readings) for the lower glass pool has ranged from 1060 to $1080^{\circ} \mathrm{C}$. In the early periods of radioactive operation, the amount of current supplied to the upper set of electrodes was typically about the same or slightly more than that supplied to the lower set 
(sometimes as much as $25 \%$ more). In June 2000 the amount of current supplied to the respective electrodes began to diverge, increasing from 916 to 1226 amps for the lower electrodes and decreasing from 923 to 729 amps for the upper electrodes (monthly averages between June 2000 and July 2001).

During testing in the Savannah River Technology Center's (SRTC) Integrated DWPF Melter System (IDMS), a pilot-scale facility at the TNX area that operated from 1988 - 1995, significant amounts of $\mathrm{Ru}\left(\mathrm{as} \mathrm{RuO}_{2}\right)$ and $\mathrm{Rh}$ settled to the melter floor. Often these noble metals were associated with spinel crystals (as nucleating agents or as isomorphic substitution in the crystal lattice or both). The electrical response of the DWPF melter is similar to observations made during the operation of the IDMS melter. Similar to that observed in the DWPF, the resistance ratio for the IDMS melter was initially stable, oscillating from 1.1 to 1.3. However, after 550 days of operation with noble metals the resistance ratio increased dramatically and continued upward, over time, to $2.3-2.5$. The sudden increase in the resistance ratio corresponded to a time when melter floor samples revealed a significant increase in the amount of material on the melter floor. Upon close examination of the date (plots are presented in Smith and Bickford, 1997), it appears that the IDMS upper-to-lower resistance ratio increased largely because of an increase in the apparent resistance in the upper glass pool. The lower glass pool resistance did have a gradual drop during a 100-day period of operation (during days 500 to 600 of operation) when the lower glass pool resistance declined from the nominal $0.10 \mathrm{ohms}$ to about $0.06 \mathrm{ohms}$. It remained at about 0.06 to $0.07 \mathrm{ohms}$ for the remainder of the operation. The upper glass pool resistance also declined during the same 100-day period, from the initial 0.12 down to about 0.10 . It then decreased to about 0.08 before beginning a steady increase up to approximately 0.15 ohms. In contrast, the DWPF melter has not had a sustained decrease in the lower melt pool resistance. The monthly average upper and lower glass pool resistances for the DWPF melter are shown in Figure 1-2. Operational significant effects are also shown on the plot. 


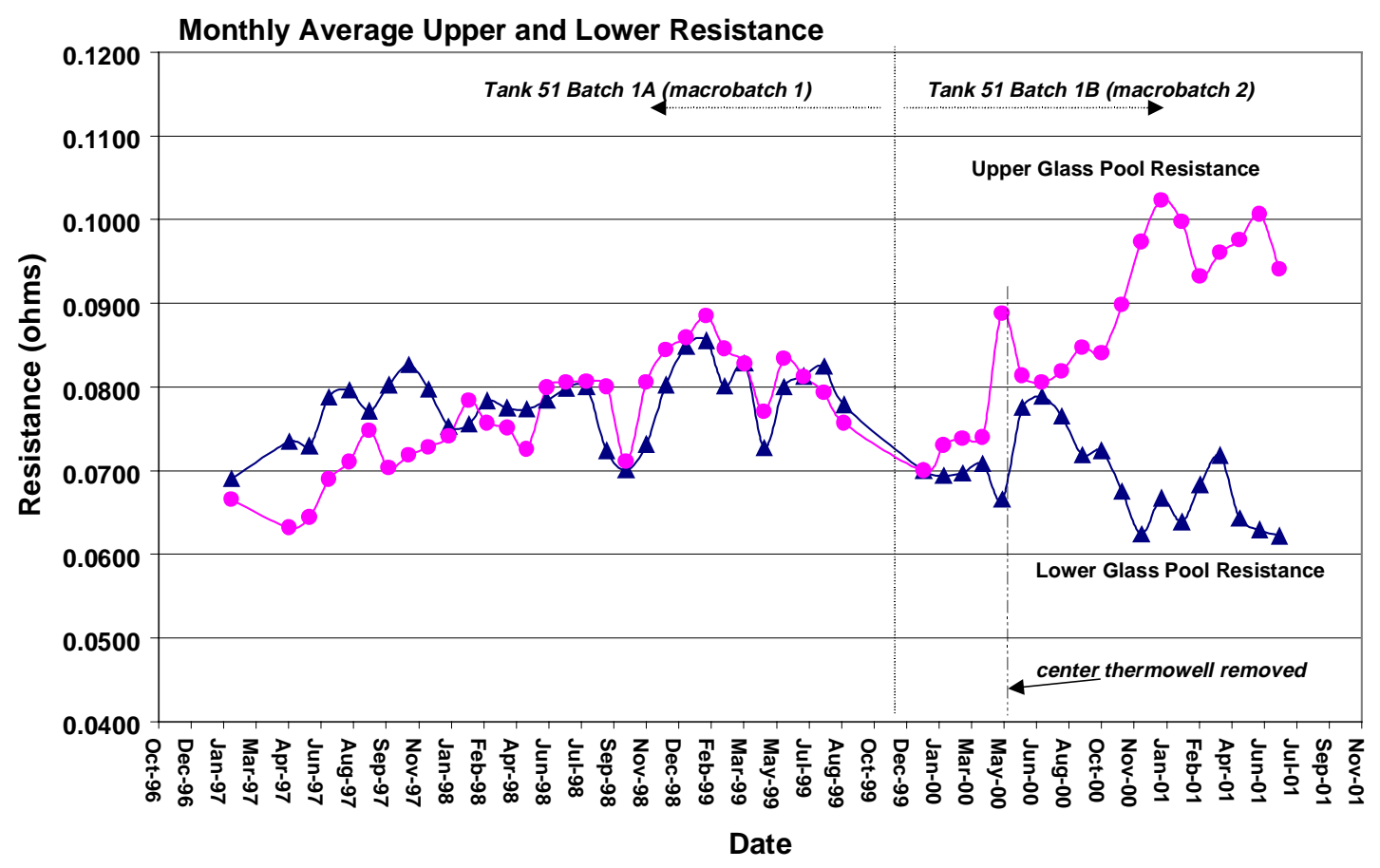

Figure 1-2. Monthly Average Upper and Lower Glass Pool Resistances

Samples taken from the IDMS melter floor suggested the accumulation of an uneven (with respect to concentration), viscous, and relatively conductive layer. However, the layer did not seem to be continuous. The accumulated noble metals and noble metal oxides seemed to be somewhat uniformly dispersed within dense accumulations of spinel crystals. Eventually, due to the accumulation of conductive material, a lower electrode current density of approximately $6.1 \mathrm{amps} / \mathrm{in}^{2}$ (compared to the design value of $5.0 \mathrm{amps} / \mathrm{in}^{2}$ ) was required to maintain the lower glass pool at $1070^{\circ} \mathrm{C}$. Note: The DWPF electrodes have consistently operated well below the $5.0 \mathrm{amps} / \mathrm{in}^{2}$ design value.

The IDMS melter was maintained at the operating temperature of approximately 1070 to $1150{ }^{\circ} \mathrm{C}$; however, it was not continuously fed and experienced many idle periods (i.e., no feeding). Analytical results from the IDMS runs suggested that the majority of the noble metals that settled in the IDMS melter did so during these idling periods. It is thought that the convection currents that are present during slurry feeding (driven by the cold slurry layer on the molten pool known as the "cold cap" and the temperature drop $(\Delta \mathrm{T})$ ) were sufficient to keep the noble metal particles suspended. The suspended noble metals then exited the melter as inclusions in the glass product. However, during extended idling periods, the convection currents were relatively minor (no cold cap coverage). The noble metals particles then settled over time in the stagnant molten glass pool. From the IDMS experience, it was recommended that the DWPF limit the number of idling periods (Smith and Bickford, 1997), and the DWPF melter has experienced relatively few periods of extended idling during its operation. Because of the much larger inner diameter, the convection currents in the DWPF melter are expected to be much lower (There are other factors, e.g., 
$\Delta \mathrm{T}$, melter geometry, feed processing, and redox that contribute to this). Also, the high pour rate and small internal diameter of the IDMS melter may have helped to increase the amount of noble metals that were pulled out through the riser.

The SRS Tank 51 sludge that has been fed to the DWPF melter has been very low in noble metals (concentration), much lower than was tested in the IDMS melter (see Table 1-1). The melter has experienced relatively few periods of extended idling. And now the DWPF is preparing to begin processing of a new batch of sludge that is much higher in noble metals. Most studies have indicated that the amount of noble metals that settle to the melter floor is greatly influenced by: 1) the concentration of the noble metals in the melt, 2) the size, shape and chemical state of the noble metals, and 3) the amount of mixing in the melter. The next sludge batch, from SRS Tank 40, is 2.7 to 6 times higher in Ru than that of Tank 51-1A (Tank 51 sludge 1A, macrobatch 1). The Rh concentration is 5 to 10 times higher in Tank 40 than in Tank 51-1A. Note: The concentration of each depends on the degree of washing. The SRS sludge is washed to remove excess aluminum and sodium. The lower value represents the "no washing" extreme and the upper value represents the "overwashed" extreme. In Research Scale Melter (RSM) studies at PNNL, the results suggested that there was a significant nonlinear increase in the amount of noble metal compounds deposited on the melter floor. With a 2-fold increase in the nominal noble metal content of the NCAW melter feed simulant there was a corresponding 9-fold increase in the fraction settling to the RSM floor (Cooper et al., 1994). The NCAW noble metals content is much closer to that of the SRS HM sludge, which is much higher than will be processed from Tank 40. So, the amount of noble metals that settle from that glass melt may not be 9-fold over that from Tank 51-1A, but, it is likely that there will be some nonlinear increase in noble metals settling from Tank 40 melter feed over than from the Tank 51-1A melter feed.

\subsection{Recommendations}

It is difficult to determine, with sufficient confidence, whether the DWPF melter has a deposition of noble metals on the floor. The melter has experienced some symptoms that would seem to be linked to the deposition of highly conductive noble metals and/or noble metal oxides. However, it is extremely difficult to separate the complex and often competing effects of the waste composition, the glass pool temperatures, and the varying operating conditions. And, while many of the electrical characteristics are similar to those observed in the IDMS melter (as a result of noble metals deposition), there has been no appreciable change in the lower melt resistance in the DWPF melter, the initial indication of deposition in the IDMS melter.

Recommendation \#1. It is extremely difficult to diagnose the extent of noble metal deposition in the DWPF melter (if there is, in fact, any at all). It is also, at this point, impossible to reliably forecast the long or short-term effects if there is accumulations. Nonetheless, it seems prudent to ensure that well thought out plans and procedures are in place in the event of an acute or protracted melter failure. 
Recommendation \#2. The DWPF should continue to monitor the ratio of the upper-to-lower melt pool resistance as one indication of accumulation of conductive material. The monthly average should be trended with time. The individual circuit resistances should also be routinely monitored and trended with time. Operational characteristics, current and/or power input, glass pool temperatures, etc. should also be monitored routinely and trended. A detailed examination of the historical data is recommended.

Recommendation \#3. The DWPF has, to date, processed sludge with a relatively low noble metals content. Future sludge batches, such as that in Tank 40, will have much higher noble metal content. Because of this, evaluations of alternative melter technologies that are not as susceptible to the effects of deposition of the insoluble noble metals should be supported (e.g., induction cold crucible melter, ICCM).

Recommendation \#4. In the event of noble metal accumulation, it may be possible to affect the resulting electrical distortions in the melter by disturbing the viscous spinel/noble metal layer. The DWPF should consider means, such as air sparging, by which a sludge layer may be disrupted. Other options, such as "Rapid Melter Draw Down" (Gentilucci, 2001) should also be considered. The use of tools that may be available or may be engineered to dislodge and redistribute deposits of noble metals and spinel crystals in situ should also be considered.

Recommendation \#5. The DWPF should consider collecting a representative sample of any accumulated material on the melter floor during extended outages between sludge batches. 


\subsection{Background}

Numerous governments worldwide have committed to stabilization of high-level nuclear waste (HLW) using vitrification. Many of the facilities use the Joule-heated ceramic melter as the means of stabilizing the high-level nuclear waste in a glass matrix. These facilities include:

- the German PAMELA facility in Mol, Belgium;

- the Tokai Vitrification Facility (TVF) in Tokai, Japan;

- the Defense Waste Processing Facility (DWPF) at the Savannah River Site in Aiken, SC;

- the West Valley Demonstration Project (WVDP) in West Valley, NY; and

- the planned Waste Treatment Plant (WTP) at the Hanford Reservation in Richland, WA.

The PAMELA facility began operation in 1985 . The TVF began radioactive operations in 1995 . The DWPF and WVDP both began radioactive operations in 1996. The Hanford WTP is in the planning, design, and construction stage.

The noble metals are defined as silver, gold, platinum and the platinum group metals: ruthenium, rhodium, palladium, osmium, and iridium. They are called noble because of their resistance to oxidation in contrast to base metals that oxidize when heated in air. They are easily reduced and all occur naturally in their elemental form. Of these, however, only ruthenium, rhodium, and palladium are present as fission products in high-level waste. (Note: The silver in the SRS defense waste is mostly from silver saddles used in iodine strippers). They are of concern because the metals and oxides (especially $\mathrm{RuO}_{2}$ ) are dense and electrically conductive. Almost all of the major production and research vitrification facilities have experienced operational problems that can be traced to the presence of noble metals in the melter. These metals and their alloys and compounds have tended to settle to the floor of Joule-heated ceramic melters. An accumulation of these dense, conductive and highly viscous materials can adversely affect the melter operation by decreasing the power release in the bulk glass in the melter. This can decrease the feed throughput capacity and diminish the melter's ability to maintain the desired operating temperature. This conductive layer can also cause non-uniform and uncontrollable current distributions at the surface of the electrodes that can lead to physical damage or failure of the electrodes.

The high level nuclear wastes of the United States are quite different from those of other countries. The nuclear wastes that the U. S. is (or will be) vitrifying are mainly those resulting from the production of nuclear materials for defense purposes. The high-level wastes in other countries (Germany, Japan, etc.) are byproducts from the reprocessing of commercial nuclear fuel. Because of the differences in the waste origins, the expected levels of noble metals in the wastes are also varied. Table 2-1 shows a comparison of noble metals concentrations for selected German, Japanese, and American wastes. As one can see in this Table, the noble metal content of the commercial 
waste (the Japanese TVF and the German WAK) is considerably higher than that of the defense wastes (SRS HM and Blend, and the Hanford NCAW). However, the flat-bottomed German PAMELA melter experienced major operational problems while processing the LEWC material. The LEWC has a noble metal content that is very similar to that of the SRS HM and the Hanford NCAW.

Table 2-1. Noble Metals in German, Japanese, and American Waste Glasses*

\begin{tabular}{lcccc}
\hline & $\begin{array}{c}\text { German } \\
\text { PAMELA }\end{array}$ & $\begin{array}{c}\text { Japanes } \\
\text { e TVF }\end{array}$ & $\begin{array}{c}\text { Savannah } \\
\text { River } \\
\text { Component }\end{array}$ & Hanford \\
& LEWC/WAK & GLASS & $\begin{array}{c}\text { HMLEN } \\
\text { D }\end{array}$ & NCAW'91 \\
\hline $\mathrm{Ru}$ & $1000 / 5100$ & 5530 & $830 / 350$ & 870 \\
$\mathrm{Pd}$ & $? / 3000$ & 2960 & $310 / 160$ & 300 \\
$\mathrm{Rh}$ & $? / 1400$ & 1290 & $150 / 68$ & 240 \\
$\mathrm{Ag}$ & trace & 93 & $20 / 77$ & 320 \\
Total & $? / 9500$ & 9873 & $1310 / 655$ & 1730 \\
\hline * Values in ppm elemental projected in the glass product &
\end{tabular}

* Values in ppm elemental projected in the glass product

Considerable testing has been done in support of the U. S. vitrification efforts. Much research has been done at the Savannah River Technology Center (SRTC), Pacific Northwest National Laboratory (PNNL), and the West Valley Demonstration Project (WVDP). PNNL conducted parametric studies in their Research Scale Melter (RSM) in Richland, WA (Cooper, et al., 1994) and sponsored testing in the Engineering Scale Melter (ESM) at the Institute für Nuklear Entsorgungstechnik at Kernforshungzentrum Karlsruhe (INE/KfK) in Karlsruhe, Germany (Grunewald et al., 1993a, 1993b). SRTC ran several small-scale melter tests before operating the Integrated DWPF Melter System (IDMS) from 1988 - 1995.

The Integrated DWPF Melter System (IDMS) was designed and constructed to provide an engineering-scale representation of the DWPF melter and its associated feed preparation and off-gas treatment systems. The facility, which operated from 1988 to 1995, was the first engineering-scale melter system capable of processing mercury and flowsheet levels of halides and sulfates (Smith et al., 1989).

In order to characterize the behavior of noble metals, 16 runs, using four types of waste simulants, were conducted in the IDMS facility. These tests were: (1) three runs using a Blend (BL) sludge (a mix of HM and PUREX sludges), (2) four runs using an HM (high noble metals, high aluminum, high viscosity) sludge, (3) seven runs using a PUREX (high iron, low viscosity) sludge, and (4) two runs using the Hanford NCAW sludge (Hutson et al, 1990, 1991a, 1991b, 1991c, 1992; Hutson, 1993a, 1993b) 
Throughout the operation, samples were taken from the melter floor. With increasing amounts of noble metals fed to the melter, there was a corresponding increase in the amount of noble metals, noble metal compounds, and spinels found on the melter floor. Samples that were taken at the center of the melter and at the outside of the floor diameter (at the face of one of the electrodes) suggested the accumulation of a non-uniform layer of noble metals and crystalline material. Analysis of these samples revealed a higher concentration of $\mathrm{RuO}_{2}$ in samples taken from the outer edges of the melt pool than those taken at the center of the melter floor. This suggests that convective currents in the melter tend to move the $\mathrm{RuO}_{2}$ from the center of the melter (where it enters) to the outside edges. Material balances of these components showed a tendency for the noble metals to be retained as $\mathrm{Ru}>\mathrm{Rh}>>\mathrm{Pd}$ and $\mathrm{Ag}$. It is estimated that the overall percent accumulations in the IDMS for the noble metals during these runs was $35 \%$ for $\mathrm{Ru}, 21 \%$ for $\mathrm{Rh}$, and close to zero percent for Pd and $\mathrm{Ag}$.

Noble metal settling was particularly obvious during melter idling (i.e., during those periods when the melter was not feeding or pouring and there was no cold cap). The characteristic settling time seemed to be reached between 10 and 20 days of idle time. Approximately $70 \%$ of the Ru in the melter at the start of an idling period settled during this critical time.

As more noble metals were fed to the IDMS melter the upper-to-lower resistance ratio increased, and therefore current requirement for the bottom electrode pair to maintain the desired melt pool temperature increased as well. Initially a current of $450 \mathrm{amps}$ was necessary to maintain a lower glass pool temperature of $1125^{\circ} \mathrm{C}$. At the end of the melter testing, $650 \mathrm{amps}$ were required to maintain a temperature of $1070^{\circ} \mathrm{C}$. However, the melter did continue to operate with acceptable performance. There was no decrease in the production capacity of the IDMS melter during the tests. A subsequent inspection of the IDMS melter showed that the bottom electrodes had sustained appreciable damage on their lower portions. This damage was probably due to high current densities caused by conductive noble metal deposits that led to preferential firing from the bottom of the electrode faces. Masses of high viscosity material (mixtures of glass, spinels and noble metals) were found at the bottom of the melter.

The ratio of upper-to-lower glass pool resistance proved to be an effective measure in indicating the accumulation of noble metals on the floor of the IDMS melter. This ratio continued to rise during the noble metals runs, thereby showing that the bottom electrode circuit resistance was being lowered. This implied that a conductive layer of material (noble metals) was forming on the melter bottom. The post shutdown inspection of the melter showed this was indeed the case.

The West Valley Demonstration melter was designed to be less susceptible to noble metals than the DWPF (which was designed in 1983). The WVDP modifications appear to have been partially successful, yet two-thirds of the electrical resistance in the WVDP melter circuits were lost after one year of operation with noble metals concentrations comparable to SRS HM waste. WVDP is actively following the electrical response of its melter. 
There are other reports that provide extensive summary of the results of various noble metal test programs (and operational experiences). Two reports (Smith and Bickford, 1997; Sundaram and Perez, 2000) are particularly thorough and more extensive than this report is intended to be. Readers of this document are strongly encouraged to consult those works for further background. 


\subsection{Noble Metals Testing in the Integrated DWPF Melter System (IDMS)}

\subsection{IDMS and DWPF Melters}

The DWPF melter is a refractory-lined, sealed, stainless steel vessel of a 6-ft internal diameter and an approximately 7-ft internal height. The 1.5-in thick vessel shell is made of SA 240-304L steel with an OD of 8'-4.5" and an ID of 8'-1.5". All shell components have a minimum two-year design life. The outer shell is water-cooled to maintain the outer vessel at or below $50^{\circ} \mathrm{C}$. Primary glass containment is achieved by use of 12 -inch thick Monofrax ${ }^{\mathrm{TM}} \mathrm{K}-3$ fused cast refractory brick (product of Carborundum Co.).

During operation, the glass is maintained in a molten condition $\left(1050-1170^{\circ} \mathrm{C}\right)$ by passing a current from the electrodes through the resistive glass pool. Electrical energy is converted to heat inside the molten glass as described by Joule's Law:

$$
P=I^{2} R
$$

where $\quad \mathrm{P}$ is the heat produced in the glass

I is the electrical current supplied by opposing electrodes, and

$\mathrm{R}$ is the resistance of the glass

The DWPF melter electrodes are four uncooled plates fabricated from Inconel ${ }^{\mathrm{TM}} 690$ of sufficient thickness to last greater than two years. The corrosion rate of the Inconel ${ }^{\mathrm{TM}} 690$ in the glass pool is expected to be less than 1.8 mils/day. The electrode stems are water-cooled.

The DWPF melter vessel shell is penetrated in the vapor space by four pairs of horizontal resistance-type Inconel ${ }^{\mathrm{TM}}$ 690 lid heater rods that are maintained at a temperature that assures adequate combustion of the organics in the vapor space. The lid heaters also provide additional heat to the glass pool to increase the melt rate.

The IDMS Melter shell is basically the same as that of the DWPF Scale Glass Melter (SGM, approximately $2 / 3^{\text {rd }}$ that of the DWPF melter shell). An additional 12 inches of Monofrax ${ }^{\mathrm{TM}} \mathrm{K}-3$ was added to the lower interior walls of the melt tank in order to reduce its diameter. The melt pool surface area of the IDMS melter is approximately $1 / 9^{\text {th }}$ that of the DWPF Melter. Melt rate is directly proportional to the surface area. Therefore, the IDMS Melter could be slurry-fed to produce glass at $25 \mathrm{lb} / \mathrm{hr}$ (the DWPF design production rate is $228 \mathrm{lb} / \mathrm{hr}$ ). Table 3-1 gives a comparison of the two melters. 
Two horizontally-entering Inconel ${ }^{\mathrm{TM}} 690$ lid heaters provided an additional $60 \mathrm{~kW}$ of heat to vaporize water from the slurry feed, melt and the glass, and combust organics in the feed. The lid heaters were maintained at $950^{\circ} \mathrm{C}$ by passing current through the tubes. 
Table 3-1. IDMS/DWPF Melter Comparison

\begin{tabular}{ccc}
\hline Parameter & IDMS Melter & DWPF Melter \\
\hline Melt surface area & $3 \mathrm{ft} 2\left(0.29 \mathrm{~m}^{2}\right)$ & $28 \mathrm{ft}^{2}\left(2.61 \mathrm{~m}^{2}\right)$ \\
Melt volume & $18 \mathrm{ft} 3\left(0.20 \mathrm{~m}^{3}\right)$ & $87.6 \mathrm{ft} 3\left(2.48 \mathrm{~m}^{3}\right)$ \\
Centerline depth & $27 \mathrm{in}(69 \mathrm{~cm})$ & $37 \mathrm{in}(95 \mathrm{~cm})$ \\
Glass content (max) & $1063 \mathrm{lbs}(482 \mathrm{~kg})$ & $13,136 \mathrm{lbs}(5956 \mathrm{~kg})$ \\
Production rate & $25 \mathrm{lb} / \mathrm{hr}(11 \mathrm{~kg} / \mathrm{hr})$ & $228 \mathrm{lb} / \mathrm{hr}(103$ \\
Melt rate & $8 \mathrm{lb} / \mathrm{hr} / \mathrm{ft}^{2}$ & $8 \mathrm{lb} / \mathrm{hr})$ \\
Residence time & $44 \mathrm{hrs}$ & $58 \mathrm{hrs}$ \\
\hline
\end{tabular}

Glass pouring from the IDMS melter was initiated by creating a vacuum at the canister relative to the melter vapor space. A flexible set of stainless steel bellows provided a vacuum seal between the melter and the canister during pouring. These cylindrical canisters were 31-in tall with a 10-in diameter. Although the slurry was fed continuously to the melter, glass was poured in batches. Additional information about the IDMS facility can be found in the start-up report (Smith et al., 1989).

Table 3-2. Characteristics of Melter Electrodes

\begin{tabular}{|c|c|c|}
\hline Characteristic & IDMS Melter & DWPF Melter \\
\hline Upper pair surface area $\left(\mathrm{ft}^{2}\right)$ & 1 & 3.3 \\
\hline Lower pair surface area $\left(\mathrm{ft}^{2}\right)$ & 0.74 & 3.3 \\
\hline Electrode power $(\mathrm{kW}) *$ & 20 & 80 \\
\hline Design current density $\left(\mathrm{amps} / \mathrm{in}^{2}\right)$ & 5 & 5 \\
\hline \multicolumn{3}{|l|}{ Distance between electrodes: } \\
\hline - across melter (in) & 21.2 & 56 \\
\hline - top and bottom (in)** & 6.75 & 10 \\
\hline - and the floor (in) ${ }^{\dagger}$ & 2.5 & -- \\
\hline
\end{tabular}

\subsection{Summary of IDMS Noble Metals Runs}

The IDMS conducted a total of 16 noble metal (or noble metal related) runs during its operation. They were conducted using four types of simulated wastes (Blend, HM, PUREX, and NCAW) with varying amounts of noble metals. Some of the sludge compositions were modified in order to judge the effects of components such as mercury and nitrite. Specific compositions of each of the sludges can be found in Campaign Summary Reports (Hutson et al., 1991; Zamecnik et al., 1993; Hutson, 1993). A general summary of conditions for each of the IDMS noble metal- 
containing runs is given in tabular form in Table 3-3. The specified noble metals amounts (in the waste sludge simulant) are given in Table 3-4. 
Table 3-3. IDMS Run Summary

\begin{tabular}{|c|c|c|c|c|c|c|c|c|c|}
\hline Run ID & & Sludge Type & РНА Туре & Frit Type & Acid Type & $\begin{array}{l}\text { Mercury } \\
\text { Amounts }\end{array}$ & $\begin{array}{c}\text { NM } \\
\text { Amounts }\end{array}$ & $\begin{array}{c}\text { Te, Se } \\
\text { Amounts }\end{array}$ & $\begin{array}{c}\text { Glass Prod } \\
\text { (lbs) }\end{array}$ \\
\hline Blend1 & BL1 & Blend & HAN & FRIT-202 & $90 \%$ Formic & Blend & Blend & Blend & 2970 \\
\hline Blend2 & BL2 & Blend & HAN & FRIT-202 & $90 \%$ Formic & Blend & Blend & Blend & 5376 \\
\hline Blend3 & BL3 & Blend & HAN & FRIT-202 & $90 \%$ Formic & None & None & None & 1595 \\
\hline HM1 & HM1 & HM & HAN & FRIT-202 & $90 \%$ Formic & None & None & None & 3156 \\
\hline HM2 & HM2 & HM & HAN & FRIT-202 & $90 \%$ Formic & None & HM & HM & 2949 \\
\hline HM3 & HM3 & $\mathrm{HM}$ & HAN & FRIT-202 & $90 \%$ Formic & None & HM & HM & 3635 \\
\hline PUREX1 & PX1 & PUREX & HAN & FRIT-202 & $90 \%$ Formic & None & HM & $\mathrm{HM}$ & 3344 \\
\hline PUREX2 & PX2 & PUREX & HAN & FRIT-202 & $90 \%$ Formic & None & HM & HM & 4232 \\
\hline HWVP1 & HV1 & NCAW & None & PNNL FY92 & $90 \%$ Formic & None & NCAW & NCAW & 3390 \\
\hline HWVP2 & $\mathrm{HV} 2$ & NCAW & None & PNNL FY92 & $90 \%$ Formic & None & NCAW & NCAW & 4561 \\
\hline HM4 & HM4 & HM & HAN & FRIT-202 & $8 \mathrm{M}$ Nitric & $\mathrm{HM}$ & $\mathrm{HM}$ & $\mathrm{HM}$ & 3226 \\
\hline PUREX3 & PX3 & PUREX & HAN & FRIT-202 & $8 \mathrm{M}$ Nitric & $\mathrm{HM}$ & HM & HM & 5108 \\
\hline PUREX4 & PX4 & PUREX & Late Wash & FRIT-202 & $8 \mathrm{M}$ Nitric & $\mathrm{HM}$ & HM & $\mathrm{HM}$ & 4850 \\
\hline PUREX5 & PX5 & PUREX & Late Wash & FRIT-202 & $8 \mathrm{M}$ Nitric & $\mathrm{HM}$ & HM & HM & 4075 \\
\hline PUREX6 & PX6 & PUREX & Late Wash & FRIT-202 & $11 \mathrm{M}$ Nitric & $\mathrm{HM}$ & HM & HM & 1693 \\
\hline
\end{tabular}

Table 3-4. Sludge Noble Metal etc. Concentrations

\begin{tabular}{ccccc}
\hline Element & $\begin{array}{c}\text { Blend } \\
\text { wt-\% }\end{array}$ & $\begin{array}{c}\text { HM } \\
\text { wt-\% }\end{array}$ & $\begin{array}{c}\text { PUREX } \\
\text { wt-\% }\end{array}$ & $\begin{array}{c}\text { NCAW } \\
\text { wt-\% }\end{array}$ \\
\hline $\mathrm{Ru}$ & 0.1 & 0.217 & 0.028 & 0.231 \\
$\mathrm{Rh}$ & 0.018 & 0.038 & 0.008 & 0.064 \\
$\mathrm{Pd}$ & 0.045 & 0.079 & 0.026 & 0.08 \\
$\mathrm{Ag}$ & 0.014 & 0.014 & 0.014 & 0.084 \\
$\mathrm{Hg}$ & 1.588 & 3.263 & 0.102 & 0 \\
$\mathrm{Te}$ & 0.022 & 0.048 & 0.006 & 0.06 \\
$\mathrm{Se}$ & 0.002 & 0.004 & 0.001 & 0.009 \\
\hline (wt-\% of the sludge soluble and insoluble solids) & &
\end{tabular}

\subsection{Behavior of the Noble Metals}

The rate of accumulation of the noble metals in the melter is a function of the size, distribution, and chemical forms of the noble metals and/or the noble metal compounds in the glass. Samples were taken from various points in the 
melter system in order to understand how the different processing steps affect these parameters. Each of these samples was examined by a variety of analytical methods.

In each of the runs, the noble metal compounds were added to the alkaline waste sludge simulant in the chemical processing vessel (the SRAT/SME). The palladium, rhodium, and silver were added as nitrate solutions. The ruthenium was purchased as $\mathrm{RuCl}_{3}$ and was subsequently converted (except for PX6 when it was added as $\mathrm{RuCl}_{3}$ ) to a nitrosylruthenium hydroxide $\left(\mathrm{RuNO}(\mathrm{OH}) \mathrm{O}_{3}\right)$ slurry, the anticipated form of the ruthenium in the SRS waste.

Feed slurry samples were taken during periods of continuous melter feeding. These samples were then dried, washed with distilled water, and centrifuged. The resulting insoluble solids were examined by Scanning Electron Microscopy/Energy Dispersive Analytical X-Ray (SEM/EDAX). These analyses revealed scattered palladium "nuggets" of about $1 \mu \mathrm{m}$ and, in melter feeds containing mercury, amalgams of $\mathrm{Hg} / \mathrm{Ag}$ and $\mathrm{Hg} / \mathrm{Ag} / \mathrm{Pd}$. No individual or amalgamated $\mathrm{Ru}$ or $\mathrm{Rh}$ particles were observed in any of the melter feed slurry solids. In general, the noble metals were present in the melter feed slurry as either very small, finely dispersed particles or as soluble salts.

During continuous feeding of the slurry simulant, a "cold cap" region forms on the surface of the molten glass. It is in this area that almost all reduction/oxidation reactions occur and gaseous vitrification products are evolved. Several times during the IDMS operation, after material had been fed to the melter to form a cold cap that sufficiently covered the molten glass, a dip sample of the cold cap region was taken. Analysis of those partially vitrified samples revealed $\mathrm{RuO}_{2}$ needles of up to $20 \mu \mathrm{m}$ long present in 20 to $50 \mu \mathrm{m}$ clusters. The samples also contained scattered $1 \mu \mathrm{m} \mathrm{AgI} \mathrm{salts,} \mathrm{RuS}_{2}$, Pd tellurides and selenides, and complex mixtures of Pd/Ag/Te/I/S/Cu. These cold cap samples also provided some evidence as to how this area physically and chemically influences the agglomeration of these species. The SEM micrographs indicated the noble metal compounds (especially the Pd) were preferentially located on the surface of the solidified foam (gas bubbles). This suggested that the frothing, which takes place as a result of vitrification off-gases may promote the growth of platinum metal nodules. It has also been suggested that palladium oxides may decompose to metallic Pd and oxygen, with the Pd transported to the melt surface within the oxygen bubble. Once at the melt surface the Pd particles may combine with other free particles to form nodules that eventually then settle to the melter floor.

The formation of deposits in the melter off-gas line has been a problem common to many slurry-fed melters. These deposits are normally composed of alkali-rich chlorides, sulfates, borates, and fluorides with entrained $\mathrm{Fe}_{2} \mathrm{O}_{3}$, spinels, and frit particles. Deposit samples that were obtained from the IDMS melter off-gas line were composed of those familiar components and also contained trace quantities of $\mathrm{RuO}_{2},(\mathrm{Ru}, \mathrm{Rh}) \mathrm{O}_{2}$, and $\mathrm{Ru} / \mathrm{Rh} / \mathrm{Te}$ mixtures and some entrained Cd compounds during the NCAW processing (Hutson, 1993). While the formation of $\mathrm{RuO}_{4}$, a toxic gas, is possible in very oxidizing conditions, most of the Ru exiting the melter was the result of entrainment rather than volatility as the $\mathrm{RuO}_{2}$ in the melter off-gas deposits were most often associated with entrained spinel crystals. 
Analysis of the soluble fraction of the melter off-gas condensate revealed very low concentrations of the noble metals. However, analysis of the insoluble solids present in the off-gas condensate showed the solids to contain $\mathrm{RuO}_{2}$ crystals, spinels, and insoluble silver halide $(\mathrm{AgI}, \mathrm{AgCl})$ salts. However, the amount of the noble metals exiting the melter through the off-gas line is small and does not significantly affect the overall mass balance of any of the elements.

The canistered glass products of several IDMS campaigns were examined by SEM/EDAX. Ruthenium was the most frequently observed of the platinum group metals in the glass product. The ruthenium was present as both individual and clustered acicular (needlelike) $\mathrm{RuO}_{2}$ crystals that were usually $<10 \mu \mathrm{m}$.

The $\mathrm{RuO}_{2}$ was also quite often associated with $(\mathrm{Ni}, \mathrm{Mn}) \mathrm{Fe}_{2} \mathrm{O}_{4}$ and $(\mathrm{Ni}, \mathrm{Mn}) \mathrm{Cr}_{2} \mathrm{O}_{4}$ spinels. It had been previously shown that $\mathrm{RuO}_{2}$ can serve as a seed for the heterogeneous nucleation of these spinels and other devitrification products (Bickford and Jantzen, 1986). The SEM/EDAX analysis of the IDMS glass also revealed spinel growth which had been nucleated by aggregates of $(\mathrm{Ru}, \mathrm{Rh}) \mathrm{O}_{2}, \mathrm{Ru} / \mathrm{Rh}, \mathrm{Ru} / \mathrm{Pd}$, and $\mathrm{Rh} / \mathrm{Pd}$. Upon further analysis using Transmission Electron Microscopy (TEM), it was found that the Ru and Rh oxides were not only acting as nucleating agents for the spinel formation, but the $\mathrm{Ru}$ and $\mathrm{Rh}$ were also substituted with other spinel components to become part of the spinel structure itself. Palladium, as $\mathrm{Pd}$ and $\mathrm{Pd} / \mathrm{Te}$, was also occasionally found in the canistered glass product. The silver is completely dissolved within the glass matrix and was never found as a separate phase.

\subsection{Material Balance}

Material balances were completed for the noble metals. Several analytical methods were used to measure the noble metals in glass and melter feed slurry. Each analytical method showed a tendency for the noble metals to be retained in the melter in the following relative amounts: $\mathrm{Ru}>\mathrm{Rh}>>\mathrm{Pd}>\mathrm{Ag}$. The estimated amount retained (as the \% of that which was fed to the melter) is given in Table 3-5.

Table 3-5. Estimated Retention of the Noble Metals in the IDMS Melter

\begin{tabular}{cc}
\hline Component & $\begin{array}{c}\text { Estimated Amount } \\
\text { Retained in Melter }\end{array}$ \\
\hline $\mathrm{Ru}$ & $35.1 \%$ \\
$\mathrm{Rh}$ & $21.2 \%$ \\
$\mathrm{Pd}$ & $<1 \%$ \\
$\mathrm{Ag}$ & $3.5 \%$ \\
$\mathrm{Te}$ & $10.5 \%$ \\
$\mathrm{Se}$ & $43.0 \%$ \\
\hline
\end{tabular}

These results suggest that palladium was nearly completely flushed from the melter. However, melter floor samples contradict this. However, except in a few samples, the Pd found on the melter floor was present as very small $(1-\mu \mathrm{m})$ 
particles and very dispersed. This, along with other analytical measurements, suggested that $<10 \%$ of the Pd was retained in the melter. As expected, very little, if any, silver was retained in the melter as the silver is readily dissolved in the borosilicate glass and no silver or silver compounds were ever found on the melter floor.

\subsection{Effects on the Melter Operation}

The electrical characteristics of the IDMS melter were constantly monitored in an effort to judge the effects of the deposition of glass insoluble components. Initially the resistance of the lower melt pool was used as an indication of the accumulation of a conductive layer on the melter floor. However, this measurement is not entirely effective in determining the extent of accumulation of deposits in that each glass composition has a different electrical resistance at a given temperature. Therefore the ratio of the upper melt pool resistance to that of the lower melt pool was monitored as the indication of conductive material on the melter floor. In using this measure, changes in the melt resistivity due to differences in glass temperature or composition were normalized. A rise in this ratio suggested an increase in the amount of conductive material on the melter floor. The resistance of the glass is calculated as follows:

$$
\text { Resistance }_{\mathrm{AB}}=\frac{\text { Voltage }_{\mathrm{AB}}}{\text { Current }_{\mathrm{AB}}}
$$

and

$$
\text { Resistance }_{\mathrm{CD}}=\frac{\text { Voltage }_{\mathrm{CD}}}{\text { Current }_{\mathrm{CD}}}
$$

so that

$$
\text { Resistance Ratio }=\frac{\text { Resistance }_{\mathrm{AB}}}{\text { Resistance }_{\mathrm{CD}}}
$$

where $\mathrm{AB}=$ upper electrode pair and $\mathrm{CD}=$ lower electrode pair

During the first 550 days of operation (many of those days were spent idling, i.e., no feeding) the ratio was stable, oscillating from 1.1 to 1.3 . The ratio then began to increase dramatically and continued upward to $2.3-2.5$. The quick increase in the resistance ratio corresponded to a time when melter floor samples revealed a significant increase in the amount of material on the melter floor. A statistical analysis of the effects of noble metals on the IDMS melter upper-to-lower resistance ratio from for all the noble metals runs from BL1 to HWVP2 (a total of 17,620 grams of noble metals were added) was done (Smith and Bickford, 1997). The conclusion was that there was 
a statistically significant (95\% confidence level) increase in this ratio as the noble metals were added the melter. During operation, the resistance of the lower glass pool decreased, thereby increasing the current requirement to the lower electrodes. Eventually a current limit (set at $600 \mathrm{amps}$ ) prevented the melter from being operated in the desired temperature range $\left(1100-1150^{\circ} \mathrm{C}\right)$. The current limit was increased and approximately 650 amps were required to maintain the lower glass pool at $1070^{\circ} \mathrm{C}$. That current slightly exceeded the design current density $(6.1$ amps/in ${ }^{2}$ versus the design value of $5.0 \mathrm{amps} / \mathrm{in}^{2}$ ).

The IDMS melter was idled for several extended periods (> 20 days). There were several reasons for this (Smith and Bickford, 1997) including the normal outages that one expects to experience in a pilot-scale research facility. The Germans noted that changes in the electrical resistance in the glass pool were especially obvious during extended periods of idling. It is thought that the convection currents present during slurry feeding (driven by the cold slurry layer on the molten pool known as the "cold cap") were sufficient to keep the noble metal particles suspended. The suspended noble metals then exited the melter as inclusions in the glass product. However, during extended idling periods, the convection currents were relatively minor (no cold cap coverage). The noble metals particles then settled easily in the stagnant molten glass pool. Plots of noble metals in the glass product showed that the concentrations (especially Ru and $\mathrm{Rh}$ ) decreased significantly during periods of idling. The concentrations then increased, toward the target concentration in a profile similar to that predicted in a Continuously Stirred Tank Reactor (CSTR), when continuous feeding was reinitiated. This indicated that most of the deposition in the IDMS melter took place during extended periods of idling.

The changes in concentration of Ru during periods of idling were examined using data from glass collected from "small pours" during idling periods. This is shown in Figure 3-1. The data followed the same general trend as a hypothetical sedimentation relationship (Smith and Bickford, 1997).

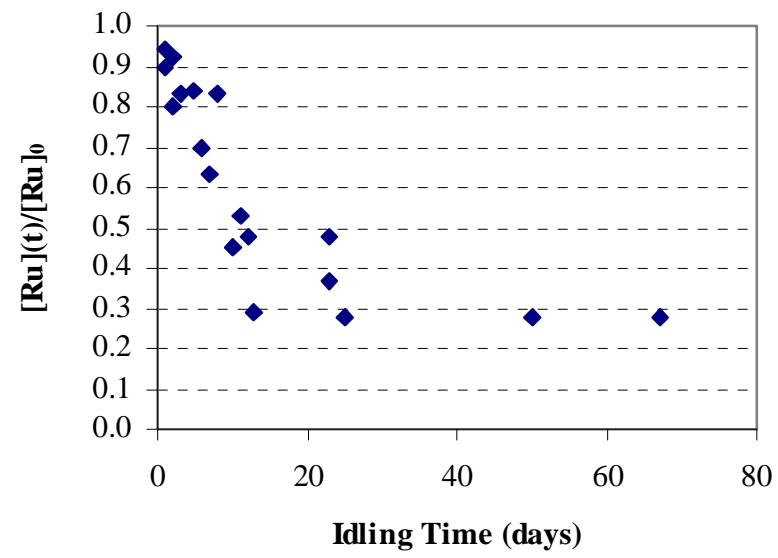

Figure 3-1. Ruthenium Settling during Periods of Idling in the IDMS Melter 
Thus one can generalize that initially the relative concentration varied linearly until a critical point is reached, and then the rate of change of concentration decreased rapidly until the ultimate concentration is reached. The data suggested that the Ru was present in the melt as particles of various sizes and shapes, some that settled easily and some that did not. The ultimate concentration represented the Ru that did not easily settle. The data indicated that the critical settling point was reached between 10 and 20 days of idle time. The data taken for idle times less than 20 days was used to generate a least-squares relationship for relative Ru concentration versus idle time for the IDMS melter. The linear region was described by:

$$
\frac{[R u](t)}{[R u]_{0}}=0.9814-0.04713 t
$$

In this equation, $t$ is idle time in days, $[R u](t)$ is the concentration of ruthenium in the melt as a function of time, and $[R u]_{0}$ is the initial ruthenium concentration in the melt (at $t=0$ ).

The ultimate relative concentration appeared to be between 0.25 and 0.30 , indicating that approximately 25 to $30 \%$ of the Ru in the melter was of a size or shape that did not settle easily.

\subsection{IDMS Melter Shutdown/Inspection}

The IDMS melter was shutdown on June 30, 1995 after operating continuously since October 1988. During deinventory of the melter, glass samples were collected from the floor and drain of the IDMS melter in an attempt to determine the composition of any species (spinels and/or noble metals) that may have crystallized and settled during the 7-year operation. An inspection of the melter refractory, melter components, and off-gas piping was also completed.

A high vacuum pour was initiated to remove as much glass from the melter as possible since it was expected that bottom draining would not be effective. Approximately twelve inches of glass remained after the completion of the high vacuum pour. An attempt was made to drain the melter through the drain valve. Repeated attempts were unsuccessful in draining any glass through the drain valve primarily because the drain valve Zone 1 heater was inoperative. The top head melter components (feed tube, level probe, thermowells) were removed from the melter. The melter power was shutdown and the melter cooled to room temperature.

After cooling, the remaining glass (approximately 12 inches) in the bottom of the melter was core-drilled and bead blasted for cleaning (analysis of these core samples is discussed in a later section). An inspection of the melter refractory, melter component, and off-gas piping, as well as sampling of the material at the bottom of the melter was done. Aggressive attack of the K-3 refractory occurred at the bottom of the melter drain. The Inconel ${ }^{\mathrm{TM}} 690$ drain valve and pipe had extensive corrosion. The Inconel ${ }^{\mathrm{TM}} 690$ upper electrode was in excellent condition above the normal glass level while the bottom of the electrode exhibited some wear. The Inconel ${ }^{\mathrm{TM}} 690$ lower electrode, continuously in contact with the melt, had lost about $12 \%$ of the material from the face of the electrode. 
Approximately two inches of material was lost from the bottom face of the lower electrodes, and the electrodes were very rounded in this area. Mechanisms considered for this are all associated with noble metals deposits; 1) low viscosity glass at hot spot near the junction of the electrodes and the glass could have accelerated wear, 2) high electrical current densities could have accelerated oxidation and electrochemical attack of the electrodes, 3) alloying of the electrodes at the surface with the noble metals, Se or Te could have adversely affected the ability of the Inconel ${ }^{\mathrm{TM}}$ to develop a passive corrosion inhibiting surface layer, and 4) localized overheating could have caused localized electrode melting.

The faces of the upper electrodes were also heavily worn, especially at the ends. The extent of the attack was proportionally higher in this melter than in other SRTC melters that had operated for comparable times. The electrodes were still functional.

The most likely cause of the high attack at the bottom of the electrodes is a combination of mechanisms 1 and 2. The general wear pattern is consistent with attack in regions of high current density, which adversely affects electrochemical corrosion rates. High current densities can also be expected to produce local high temperature regions, especially in normally stagnant areas such as under the bottom electrodes. There was no direct indication of electrode melting which has been seen in smaller melters and which generally produces a melter short.

Noble metal alloying and enhanced corrosion is unlikely to have been an effect since the thermowell was examined in detail and this mechanism was not observed. However, it is possible that the combination of noble metals and the electrical currents at the electrode faces resulted in such an effect. Detailed metallurgical examination of the electrode would be necessary to determine the actual mechanism. 


\subsection{Melter Core Samples and Floor Deposits}

\subsection{Floor Samples Taken During Operation}

After introduction of noble metals in the IDMS melter, samples of the melter floor were routinely taken. The samples were taken using a "grain thief" type of sampling device. The samples were normally taken through the feed tube port (center of the melt pool), but were also taken at times at the borescope port (near the face of one of the electrodes near the sidewall).

About 2 months after feeding the initial noble metal-doped slurry, a sample was taken of the melter floor (actually at about 1 - 2 inches above the floor). The sample revealed no evidence of the presence of any noble metals or crystalline material. Another sample of the melter floor (again at about 1-2 inches) was taken approximately 5 months after the initial floor sample. That sample showed very scattered $\mathrm{RuO}_{2}$ needles approximately $5-15 \mu \mathrm{m}$ in length. The needles were present, for the most part, in 20 - $40 \mu \mathrm{m}$ clusters. There was no evidence of any deposition of $\mathrm{Pd}, \mathrm{Rh}, \mathrm{Ag}, \mathrm{Se}, \mathrm{Te}$ or any of their compounds.

Approximately 13 months after the introduction of the noble metals, a third melter floor sample was taken. The sampler was modified to allow samples to be taken within 1/2-in of the melter floor. The sample revealed a significant increase in the amount of $\mathrm{RuO}_{2}$, compared to that of the earlier samples. There was also evidence of a small amount of Pd deposition. The sample was, however, relatively free of spinel accumulation.

Since there was a considerable increase in the amount of deposited $\mathrm{RuO}_{2}$, the frequency of melter floor sampling was increased and another sample was taken at 15 months into noble metal operations. This sample was taken just before the start of the feeding of the first batch of NCAW (Hanford) feed slurry. SEM micrographs of that sample revealed a dense layer of melt insolubles, mainly $\mathrm{RuO}_{2}$ and $(\mathrm{Ni}, \mathrm{Mn})(\mathrm{Fe}, \mathrm{Cr})$ spinels. That sample also revealed the first evidence of $\mathrm{Rh}$ deposition on the melter floor. During the sampling, it was noted that there was an obvious layer on the melter floor that was much more viscous than the bulk glass. This viscous layer (estimated at approximately 1-2 inches) was noted with all subsequent samplings.

Another sample was taken at 16.5 months into processing, during the feeding of the HWVP1 melter feed slurry. That sample again revealed significant $\mathrm{RuO}_{2}$ and spinel accumulation and individual metallic Pd. After the completion of the feeding of the HWVP1 melter feed, a sample was taken of the melter floor (17 months). That sample revealed dense $\mathrm{RuO}_{2}$ and spinel accumulation and scattered $\mathrm{Rh}$.

A melter floor sample was taken after completion of the feeding of the HWVP2 slurry (19 months). The sample was chemically analyzed but not examined by the microscope. The chemical analysis indicated that the $\mathrm{Ru}, \mathrm{Rh}$, and spinel components ( $\mathrm{Cr}, \mathrm{Mn}$, and $\mathrm{Fe}$ ) had all decreased, suggesting that the noble metals and spinels had been 
"flushed" from the melter or possibly rearranged on the melter floor. Plots of the components in the glass produced during the HWVP operations showed an abrupt increase in Ni and $\mathrm{Cr}$ (spinel components) between HWVP1 and HWVP2. This, along with SEM examination and chemical analysis of melter floor samples (taken at the center) gave further support to the notion that the spinels were moved from the melter center to the outer edge and flushed out with the glass. However, although the $\mathrm{RuO}_{2}$ seemed to also be moved from the center to the outside edge, it was not flushed. The concentration of Ru in the glass product decreased with the idling time between HWVP1 and HWVP2, thereby indicating settling of $\mathrm{RuO}_{2}$ from the bulk melt and an increase in the concentration of $\mathrm{RuO}_{2}$ on the melter floor. This apparent spinel flushing is not possibly advantageous with respect to increasing the lifetime of the melter. Since the spinels are not highly conductive, compared to the noble metal compounds, they may behave as insulators and increase the overall resistance of the deposited material.

Another sample was taken at 19.5 months into noble metals operations. The sample was the first taken through the borescope port. The sampling point was just at the face of the bottom electrode closest to the riser throat entrance. The SEM examination revealed that there was much less accumulation of spinels than in previous samples. Chemical analysis confirmed that the spinel components $(\mathrm{Cr}, \mathrm{Fe}$, etc. $)$ were lower than previous samples. However, the concentration of ruthenium was much higher $(9 \mathrm{wt}-\%)$ than in previous samples. This further supported the notion that the spinels had been flushed out while the $\mathrm{RuO}_{2}$ was merely swept from the center of the melter to the outside of the melter floor. SEM micrographs also revealed the normal $\mathrm{RuO}_{2}$ clusters, $\mathrm{Rh}$-nucleated $\mathrm{Cr} / \mathrm{Ni} / \mathrm{Fe}$ spinel, and an elongated formation of ruthenium disulfide, $\mathrm{RuS}_{2}$. The presence of $\mathrm{RuS}_{2}$ in this sample was surprising since this compound decomposes at temperatures $>1000^{\circ} \mathrm{C}$. This suggests that the temperatures at the outside portion of the melter may have been $<1000^{\circ} \mathrm{C}$ despite the fact that the bulk glass temperature was held at $1100-1150{ }^{\circ} \mathrm{C}$.

Another floor sample was then taken from the center of the melter (feed tube port) at 20 months. That sample revealed large amounts of deposited material, mainly $\mathrm{RuO}_{2}$ and spinels. The next sample was taken from the borescope port after 21 months. The sample showed a dense accumulation of noble metals and spinels and again confirmed the presence of $\mathrm{RuS}_{2}$. The analysis of this sample confirmed an increase in spinel components (especially $\mathrm{Cr})$.

Table 4-1 (feed tube port) and Table 4-2 and show the amounts (in wt-\%) of selected components in each melter floor sample. These results suggest the progressive formation of a non-uniform layer of noble metals (mainly $\mathrm{RuO}_{2}$ ) and $\mathrm{Ni} / \mathrm{Fe} / \mathrm{Cr}$ spinels on the melter floor. The analyses of the samples that were taken at the borescope port tended to have a higher concentration of Ru as compared to the samples taken from center of the melter (feed tube port).

Table 4-1. Analysis of IDMS Melter Floor Samples Taken during Operation from the Feed Tube Port (the center of the melt pool)

\begin{tabular}{lllllllllll}
\hline Sample & Sample & Ag & Cr & Fe & Mn & Ni & Pd & Rh & Ru & Zr
\end{tabular}




\begin{tabular}{ccccccccccc} 
ID & Date & wt-\% & wt-\% & wt-\% & wt-\% & wt-\% & wt-\% & wt-\% & wt-\% & wt-\% \\
\hline I-3701 & $2 / 25 / 91$ & & 0.10 & 8.14 & 1.65 & 0.63 & & & $<0.01$ & 0.04 \\
I-4313 & $8 / 23 / 91$ & 0.01 & & & & & 0.03 & 0.01 & 0.02 & \\
I-4790 & $10 / 15 / 91$ & $<0.01$ & 0.82 & 8.89 & 2.45 & 1.81 & 0.07 & 0.41 & 4.68 & 0.04 \\
H-0330 & $12 / 4 / 91$ & $<0.01$ & 3.19 & 11.08 & 2.52 & 1.21 & 0.02 & 0.03 & 0.42 & 0.63 \\
H-0329 & $12 / 18 / 91$ & 0.02 & 3.40 & 9.01 & 1.23 & 1.07 & $<0.01$ & 0.30 & 6.20 & 1.39 \\
I-4804 & $2 / 18 / 92$ & 0.03 & 0.51 & 4.35 & 0.43 & 0.61 & 1.01 & 0.93 & 7.33 & 2.02 \\
I-5242 & $3 / 27 / 92$ & & & 4.39 & & & & & 5.53 & \\
I-6670 & $10 / 29 / 92$ & 0.03 & 0.25 & 6.40 & 1.18 & 0.84 & 0.33 & 0.46 & 4.73 & 0.59 \\
I-8228A & $9 / 28 / 94$ & $<0.018$ & 0.50 & 5.99 & 0.86 & 1.01 & $<0.136$ & 0.37 & 4.22 & 0.50 \\
I-8228B & $9 / 28 / 94$ & $<0.021$ & 0.46 & 4.67 & 1.14 & 1.33 & $<0.155$ & 1.41 & 15.60 & 0.64 \\
\hline
\end{tabular}

Table 4-2. Analysis of IDMS Melter Floor Samples Taken during Operation from the Borescope Port (at the face of the electrode near the riser throat)

\begin{tabular}{ccccccccccc}
\hline $\begin{array}{c}\text { Sample } \\
\text { ID }\end{array}$ & $\begin{array}{c}\text { Sample } \\
\text { Date }\end{array}$ & $\begin{array}{c}\text { Ag } \\
\text { wt-\% }\end{array}$ & $\begin{array}{c}\text { Cr } \\
\text { wt-\% }\end{array}$ & $\begin{array}{c}\text { Fe } \\
\text { wt-\% }\end{array}$ & $\begin{array}{c}\text { Mn } \\
\text { wt-\% }\end{array}$ & $\begin{array}{c}\text { Ni } \\
\text { wt-\% }\end{array}$ & $\begin{array}{c}\text { Pd } \\
\text { wt-\% }\end{array}$ & $\begin{array}{c}\text { Rh } \\
\text { wt-\% }\end{array}$ & $\begin{array}{c}\text { Ru } \\
\text { wt-\% }\end{array}$ & $\begin{array}{c}\text { Zr } \\
\text { wt-\% }\end{array}$ \\
\hline I-5219 & $3 / 6 / 92$ & 0.03 & 0.49 & 4.78 & 0.46 & 0.47 & 0.08 & 0.27 & 9.59 & 2.11 \\
I-5270 & $4 / 20 / 92$ & $<0.01$ & 1.94 & 4.52 & 0.75 & 1.16 & $<0.01$ & 0.14 & 11.40 & 1.00 \\
I-6823 & $7 / 22 / 93$ & $<0.01$ & 0.24 & 6.37 & 1.12 & 0.81 & $<0.01$ & 0.59 & 8.85 & 0.51 \\
I-8227 & $9 / 28 / 94$ & $<0.018$ & 1.08 & 6.38 & 1.13 & 1.31 & $<0.138$ & 0.58 & 5.65 & 0.63 \\
\hline
\end{tabular}

The accumulation of $\mathrm{RuO}_{2}$ and $\mathrm{Rh} / \mathrm{Pd} / \mathrm{Te}$ is consistent with that observed in waste vitrification simulations in Germany (Krause and Luckscheiter, 1991). However, in melter floor samples taken from a research melter in Karlsruhe, Germany, the $\mathrm{RuO}_{2}$ needles were much more acicular and perfectly formed. The $\mathrm{RuO}_{2}$ crystalline growth in SRS, Hanford, and West Valley glasses and cold cap samples appeared to be inhibited by the glass itself. This may be explained by the fact that glass beads are used as the primary glass forming additive in German tests while tests conducted in the IDMS facility and the West Valley SFCM used a finely ground glass frit and batch chemicals. The "large" voids present between the glass beads of the German slurry feed allowed unhindered growth of the $\mathrm{RuO}_{2}$ crystals in the cold cap. The frits used in U. S. melters soften at lower temperatures than the German glass beads and eliminate the voids in the cold cap thus hindering the growth of the $\mathrm{RuO}_{2}$ crystals.

\subsection{Post Shutdown Floor Melter Samples}

After the melter was de-inventoried as much as possible, it was allowed to cool and the remaining glass (approximately 12 inches) in the bottom of the melter was core-drilled. A total of 38 core samples were obtained radially between $0-6$ inches of the bottom drain, between $6-12$ inches, and $>12$ inches from the centrally located drain on the melter floor. These samples were analyzed at the Savannah River Technology Center (SRTC) for the following: 
- glass and deposit composition

- noble metal concentration

- $\quad \mathrm{x}$-ray diffraction identification of crystalline species

- quantitative analysis of the wt-\% spinels in the glass

- $\quad$ redox ratio $\left(\mathrm{Fe}^{+2} / \mathrm{Fe}_{\text {total }}\right)$

Three samples were taken from each core drill of the 12" of glassy deposits on the melter floor. Replicate \#1 was furthest from the refractory and Replicate \#3 was closest to the refractory floor. All of the glass/deposit compositions summed to $100 \pm 5 \mathrm{wt}-\%$ indicating that the samples had been completely analyzed. Only slight enrichment in $\mathrm{Cr}_{2} \mathrm{O}_{3}$ $(\sim 0.5 \mathrm{wt}-\%)$ was noticed over the flow sheet amounts run during the lifetime of the IDMS.

All of the melter core samples were analyzed chemically for noble metal content and by quantitative x-ray diffraction for spinel content. The results indicate that the concentration of noble metals and spinels was fairly uniform in the melter core samples taken from the 12" of glass remaining in the IDMS melter. The range of Ru was between $0.022-$ $0.041 \mathrm{wt}-\%$, the range of Rh was between $0.007-0.012 \mathrm{wt}-\%$, the range of Pd was between $0.016-0.026 \mathrm{wt}-\%$. Analysis by x-ray diffraction (XRD) confirmed that the $\mathrm{Ru}$ was present as $\mathrm{RuO}_{2}$. The wt-\% spinel, nominally $\mathrm{NiFe}_{2} \mathrm{O}_{4}$, was between $3.2-8.5$ wt- $\%$.

A sodium magnesium chromium silicate (krinovite) was found in every $\mathrm{x}$-ray diffraction spectra as well. No quantitative weight percent analysis was made of this specie, as quantitative x-ray diffraction calibration curves were not available. Krinovite is a known decomposition product of K-3 refractory (Jantzen and Lambert, 1997).

Bead blasting (similar to sand blasting but using larger-size particles that are capable of chipping away at the glass without damaging the melter refractory) and mechanical chipping were used to remove the remaining glass from the melter. No samples were taken since the melter floor glass/deposit material would have been contaminated with the bead material. After the bead blasting was complete, there were still some "blobs" of glassy/deposit material that were attached to the refractory. These blobs were easily removed from the refractory. (Note: Unfortunately no record exists to map the location of these samples). A total of 10 samples were analyzed by the same methods used for the core-drilled samples. Many of the composition analyses summed to less than $100 \pm 5 \mathrm{wt}-\%$ indicating that the samples had not adequately dissolved during wet chemical analysis. The SRTC sample preparation analyst noted the presence of undissolved residues after sample preparation/dissolution. This is because many spinel compositions are refractory and are very difficult to dissolve with the dissolution techniques used for glass analysis.

Selected components of the floor deposits are given in Table 4-3. Even though the dissolution was incomplete it was obvious from the analyses that these deposits are highly enriched in $\mathrm{Cr}_{2} \mathrm{O}_{3}, \mathrm{Fe}_{2} \mathrm{O}_{3}$, and $\mathrm{ZrO}_{2}$ over the amounts of these materials run during the lifetime of the IDMS. The embedded deposits were also somewhat enriched in $\mathrm{MgO}$. The high $\mathrm{ZrO}_{2}$ content is likely accumulation from the high $\mathrm{ZrO}_{2}$ Hanford glass that was run in the IDMS HWVP 
campaigns. However, the $\mathrm{NiO}$ content of the melter floor samples was surprisingly low; it was actually comparable to the average concentrations of Ni in melter feed over the IDMS operation (Jantzen and Lambert, 1997). The embedded deposits were also more reduced than the bulk glass. The melter floor samples (BLOBS) had an average $\mathrm{Fe}^{+2} / \mathrm{Fe}_{\text {total }}$ of 0.135 as compared to 0.065 for the melter core samples.

All of the embedded samples were analyzed for noble metal content and analyzed by quantitative x-ray diffraction. The results given in Table 4-3 indicate that the concentration of spinels ranged from 27 - $66 \mathrm{wt}-\%$. The range of Ru was also highly enriched and varied between $0.16-7.74 \mathrm{wt}-\%$. The range of Rh is between $0.026-1.21 \mathrm{wt}-\%$, the range of Pd is between $0.031-0.17 \mathrm{wt}-\%$. Again, $\mathrm{X}$-ray diffraction analysis confirmed that the Ru was present as $\mathrm{RuO}_{2}$. A sodium magnesium chromium silicate $\left(\mathrm{NaMg}_{2} \mathrm{CrSi}_{3} \mathrm{O}_{10}\right)$ and a $\mathrm{Cr}$-rich spinel (possibly containing $\mathrm{Mg}$ and $\mathrm{Al})$ phase were also found in every $\mathrm{x}$-ray diffraction spectra. 
Table 4-3. Wt-\% Concentration of Spinel and Noble Metals (Ru, Rh, and Pd) from IDMS Floor Samples

\begin{tabular}{ccccccccc}
\hline Sample ID & $\begin{array}{c}\text { Spinel } \\
\text { Wt-\% }\end{array}$ & $\begin{array}{c}\text { Ru } \\
\text { Wt-\% }\end{array}$ & $\begin{array}{c}\text { Rh } \\
\text { Wt-\% }\end{array}$ & $\begin{array}{c}\text { Pd } \\
\text { Wt-\% }\end{array}$ & $\begin{array}{c}\mathbf{F e} \\
\mathbf{W t - \%}\end{array}$ & $\begin{array}{c}\mathbf{N i} \\
\mathbf{W t - \%}\end{array}$ & $\begin{array}{c}\mathbf{C r} \\
\mathbf{W t - \%}\end{array}$ & $\begin{array}{c}\mathbf{F e}^{\mathbf{2 +}} \\
\mathbf{F e}_{\text {total }}\end{array}$ \\
\hline Core Max & 8.5 & 0.041 & 0.012 & 0.026 & - & - & - & - \\
Core Min & 3.2 & 0.022 & 0.007 & 0.016 & - & - & - & - \\
Core Avg & - & - & - & - & 7.86 & 1.31 & 0.75 & 0.065 \\
BLOB-1 & 42 & 0.330 & 0.078 & 0.068 & 19.74 & 0.45 & 14.09 & 0.142 \\
BLOB-2 & 66 & 1.120 & 0.026 & 0.062 & 15.96 & 0.80 & 14.53 & - \\
BLOB-3 & 33 & 5.370 & 0.069 & 0.041 & 13.54 & 0.99 & 10.10 & 0.034 \\
BLOB-4 & 29 & 7.740 & 1.210 & 0.066 & 12.82 & 0.73 & 7.78 & 0.019 \\
BLOB-5 & 27 & 5.660 & 1.000 & 0.160 & 13.08 & 0.32 & 11.51 & - \\
BLOB-6 & 51 & 1.190 & 0.210 & 0.083 & 14.52 & 0.33 & 17.51 & - \\
BLOB-7 & 48 & 0.160 & 0.062 & 0.075 & 12.95 & 0.42 & 17.93 & 0.111 \\
BLOB-8 & 27 & 0.410 & 0.130 & 0.031 & 12.72 & 1.01 & 7.74 & 0.093 \\
BLOB-9 & 36 & 1.600 & 0.390 & 0.140 & 15.68 & 0.57 & 11.88 & 0.166 \\
BLOB-10 & 44 & 1.700 & 0.410 & 0.170 & 16.55 & 0.64 & 12.85 & 0.193 \\
\hline
\end{tabular}

\subsection{Electrical Conductivity Measurements}

Several samples from the IDMS were sent to the Pacific Northwest National Laboratory for physical characterization. Samples taken during operation (see section 4.1) and samples taken after the shutdown and inspection (the "BLOB" samples described above) were sent to PNNL for SEM and optical microscopy and for measurement of high temperature conductivity. An example micrograph of BLOB-10 is shown in Figure 4-1.

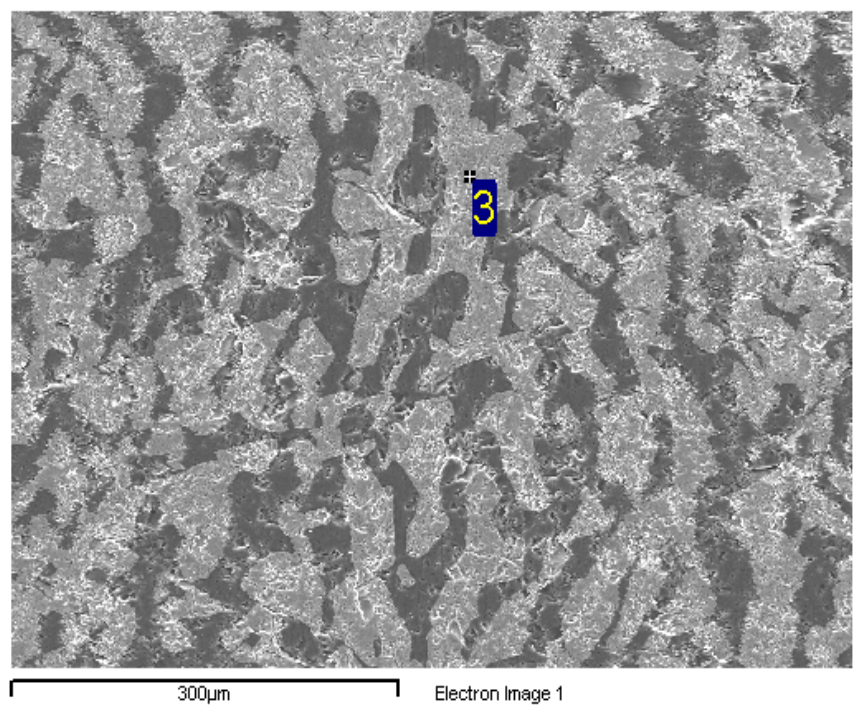

Figure 4-1. SEM Micrograph of IDMS Melter Floor Sample (BLOB-10).

(This micrograph shows dense accumulation of $\mathrm{Ni}, \mathrm{Cr}$, $\mathrm{Fe}$ spinel crystals.) 
Approximately 200-g of material was needed for the conductivity measurement. The quantities of the IDMS core and operational samples were insufficient for this measurement. Only the BLOB samples were of sufficient quantity. However, because of the high spinel content of the BLOB samples (see Table 4-3), many would not melt at the measurement temperature $\left(950-1350{ }^{\circ} \mathrm{C}\right)$. Table $4-4$ gives a summary of the temperature at which the various samples began to melt (or not). The conductivity measurements could only be made using samples BLOB-3, BLOB4, BLOB-5, and BLOB-8.

Table 4-4. Melting temperatures for IDMS melter floor samples

\begin{tabular}{lc}
\hline Sample ID & $\begin{array}{c}\text { Began To Melt } \\
\left({ }^{\circ} \mathbf{C}\right)\end{array}$ \\
\hline BLOB-1 & Did Not Melt \\
BLOB-2 & Insufficient Sample \\
BLOB-3 & 1000 \\
BLOB-4 & 800 \\
BLOB-5 & 800 \\
BLOB-6 & Insufficient Sample \\
BLOB-7 & Did Not Melt \\
BLOB-8 & 1000 \\
BLOB-9 & 1100 \\
BLOB-10 & Did Not Melt \\
\hline
\end{tabular}

The results of the conductivity measurements are given in Table 4-5. The DWPF Start-up Frit (Black Frit-165) was also measured as a reference. The results are also shown as plots in Figures 4-2 and 4-3. These figures show that the melter floor (BLOB) material may be considerably more electrically conductive than the bulk glass at the operating temperature of $1150{ }^{\circ} \mathrm{C}$. The sample with the highest noble metal content (BLOB-4, $[\mathrm{Ru}]=7.74 \mathrm{wt}-\%$, $[\mathrm{NM}]=9.02 \mathrm{wt}-\%$ ) had a conductivity more than seven times that of the DWPF start-up frit. Figure 4-4 shows the relationship between the resistance (ohms) at $1150{ }^{\circ} \mathrm{C}$ and the total noble metal content of the melter floor sample. There is a considerable drop in the resistance with an increase of noble metal content. Figure 4-5 shows the relationship between the conductivity $(\mathrm{S} / \mathrm{m})$ at $1150^{\circ} \mathrm{C}$ and the total noble metal content of the melter floor sample. The variation in the noble metal and spinel content of these (and the resulting conductivity) shows, again, that the floor deposits are non-uniform and non-continuous. 
Table 4-5. Conductivity / Resistance of IDMS melter floor samples

\begin{tabular}{|c|c|c|c|c|c|}
\hline $\begin{array}{c}\text { Temperature } \\
\left({ }^{\circ} \mathbf{C}\right)\end{array}$ & $\begin{array}{c}\text { Temperature } \\
\text { (K) }\end{array}$ & $\begin{array}{c}\text { Temperature } \\
1 / T(K) * 10000\end{array}$ & $\begin{array}{c}\text { Resistance } \\
\text { (ohms) }\end{array}$ & $\begin{array}{l}\text { Resistance } \\
\text { Corrected* }\end{array}$ & $\begin{array}{c}\text { Conductivity } \\
(\mathrm{S} / \mathrm{m})\end{array}$ \\
\hline \multicolumn{6}{|c|}{ DWPF Start-up Frit } \\
\hline 1345 & 1618 & 6.18 & 0.76 & 0.67 & 50.12 \\
\hline 1248 & 1521 & 6.57 & 1.00 & 0.92 & 36.69 \\
\hline 1148 & 1421 & 7.04 & 1.46 & 1.37 & 24.53 \\
\hline 1048 & 1321 & 7.57 & 2.24 & 2.16 & 15.58 \\
\hline 947 & 1220 & 8.20 & 3.92 & 3.84 & 8.76 \\
\hline \multicolumn{6}{|l|}{ IDMS BLOB-3 } \\
\hline 1347 & 1620 & 6.17 & 0.36 & 0.27 & 122.33 \\
\hline 1249 & 1522 & 6.57 & 0.51 & 0.42 & 80.00 \\
\hline 1150 & 1423 & 7.03 & 0.73 & 0.64 & 52.36 \\
\hline 1048 & 1321 & 7.57 & 1.18 & 1.10 & 30.66 \\
\hline 951 & 1224 & 8.17 & 2.02 & 1.94 & 17.35 \\
\hline \multicolumn{6}{|l|}{ IDMS BLOB-4 } \\
\hline 1345 & 1618 & 6.18 & 0.16 & 0.07 & 462.39 \\
\hline 1245 & 1518 & 6.59 & 0.19 & 0.10 & 325.16 \\
\hline 1145 & 1418 & 7.05 & 0.26 & 0.18 & 188.76 \\
\hline 1044 & 1317 & 7.59 & 0.51 & 0.43 & 78.38 \\
\hline 945 & 1218 & 8.21 & 1.19 & 1.11 & 30.38 \\
\hline \multicolumn{6}{|l|}{ IDMS BLOB-5 } \\
\hline 1346 & 1619 & 6.18 & 0.29 & 0.20 & 171.14 \\
\hline 1248 & 1521 & 6.57 & 0.32 & 0.23 & 146.72 \\
\hline 1149 & 1422 & 7.03 & 0.41 & 0.32 & 105.00 \\
\hline 1049 & 1322 & 7.56 & 0.60 & 0.51 & 65.54 \\
\hline 948 & 1221 & 8.19 & 1.17 & 1.09 & 30.79 \\
\hline \multicolumn{6}{|l|}{ IDMS BLOB-8 } \\
\hline 1346 & 1619 & 6.18 & 0.55 & 0.46 & 72.62 \\
\hline 1248 & 1521 & 6.57 & 0.89 & 0.80 & 41.98 \\
\hline 1148 & 1421 & 7.04 & 1.30 & 1.22 & 27.60 \\
\hline 1049 & 1322 & 7.57 & 2.05 & 1.96 & 17.12 \\
\hline 948 & 1221 & 8.19 & 3.62 & 3.53 & 9.51 \\
\hline
\end{tabular}




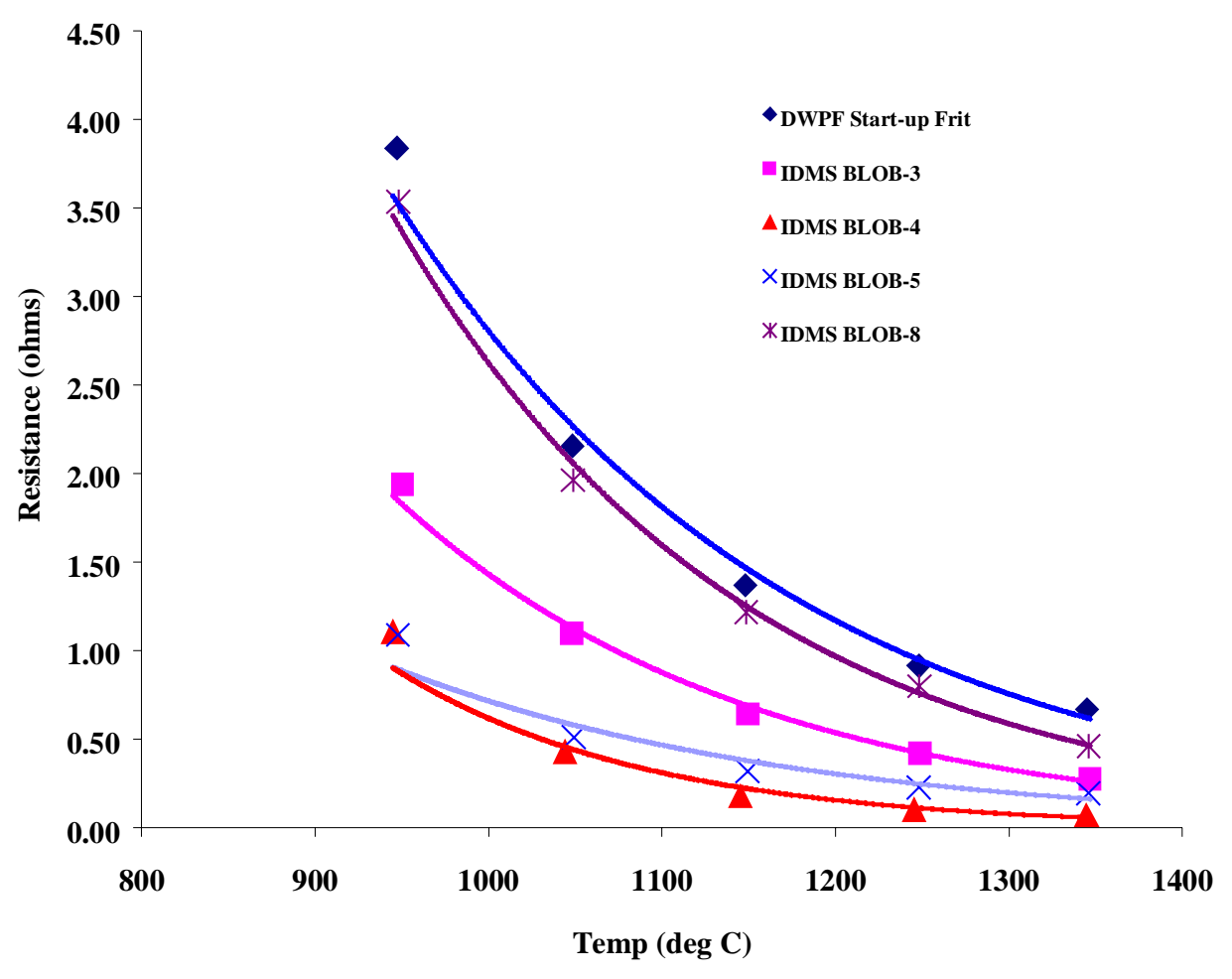

Figure 4-2. Resistance (ohms) versus Temperature $\left({ }^{\circ} \mathrm{C}\right)$ for IDMS melter floor samples (with DWPF Start-up Frit shown as a reference point)

The data were fit to an exponential equation (Eqn 4-1) relating resistance $(\Omega$, ohms) of the glassy material to temperature $\left(\mathrm{T},{ }^{\circ} \mathrm{C}\right)$. The fitting parameters for each material is given in Table 4-6.

$$
\Omega(\mathrm{ohms})=\mathrm{Ae}^{\mathrm{BT}\left({ }^{\circ} \mathrm{C}\right)}
$$

Table 4-6. Fitting parameters for relationship between Resistance and Temperature

\begin{tabular}{lccc}
\hline Material & A & B & $\mathbf{R}^{\mathbf{2}}$ \\
\hline DWPF Start-up Frit & 221.19 & -0.0044 & 0.9888 \\
IDMS Blob \#3 & 191.68 & -0.0049 & 0.9950 \\
IDMS Blob \#4 & 589.93 & -0.0069 & 0.9655 \\
IDMS Blob \#5 & 51.059 & -0.0043 & 0.9363 \\
IDMS Blob \#8 & 383.71 & -0.0050 & 0.9971 \\
\hline
\end{tabular}




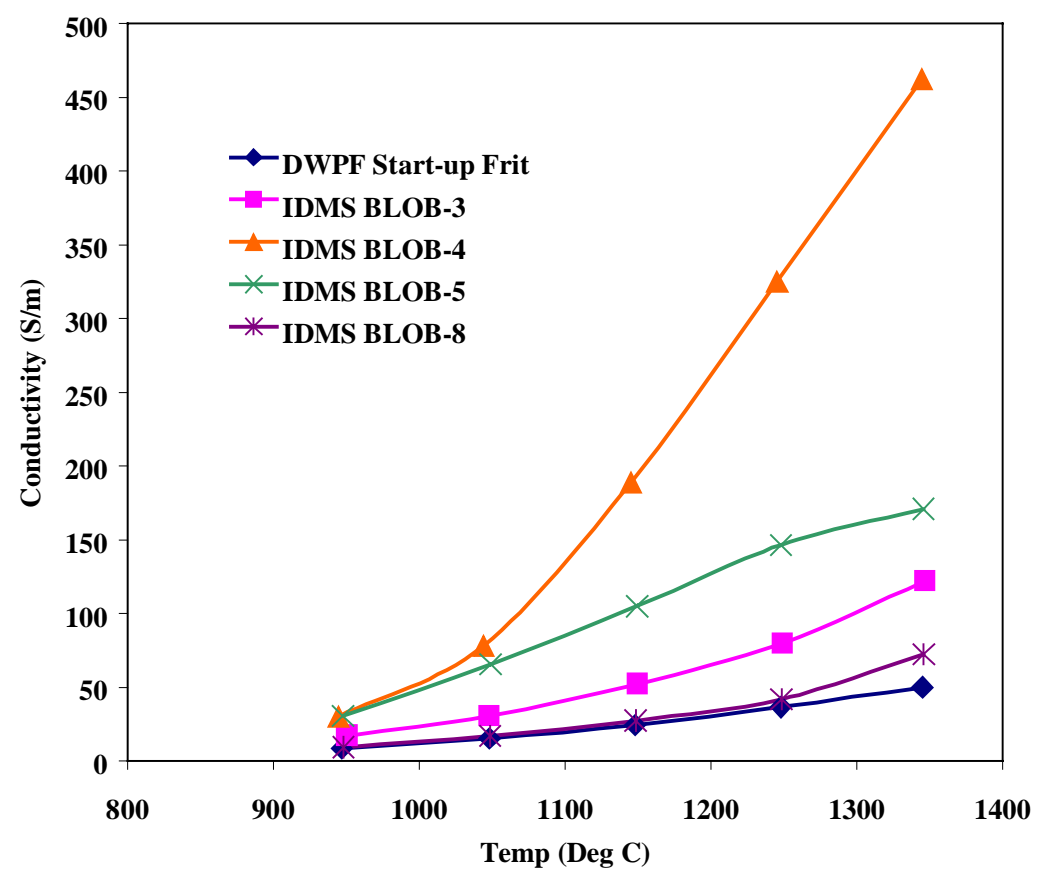

Figure 4-3. Conductivity $(\mathrm{S} / \mathrm{m})$ versus Temperature $\left({ }^{\circ} \mathrm{C}\right)$ for IDMS melter floor samples (with DWPF Start-up Frit shown as a reference point)

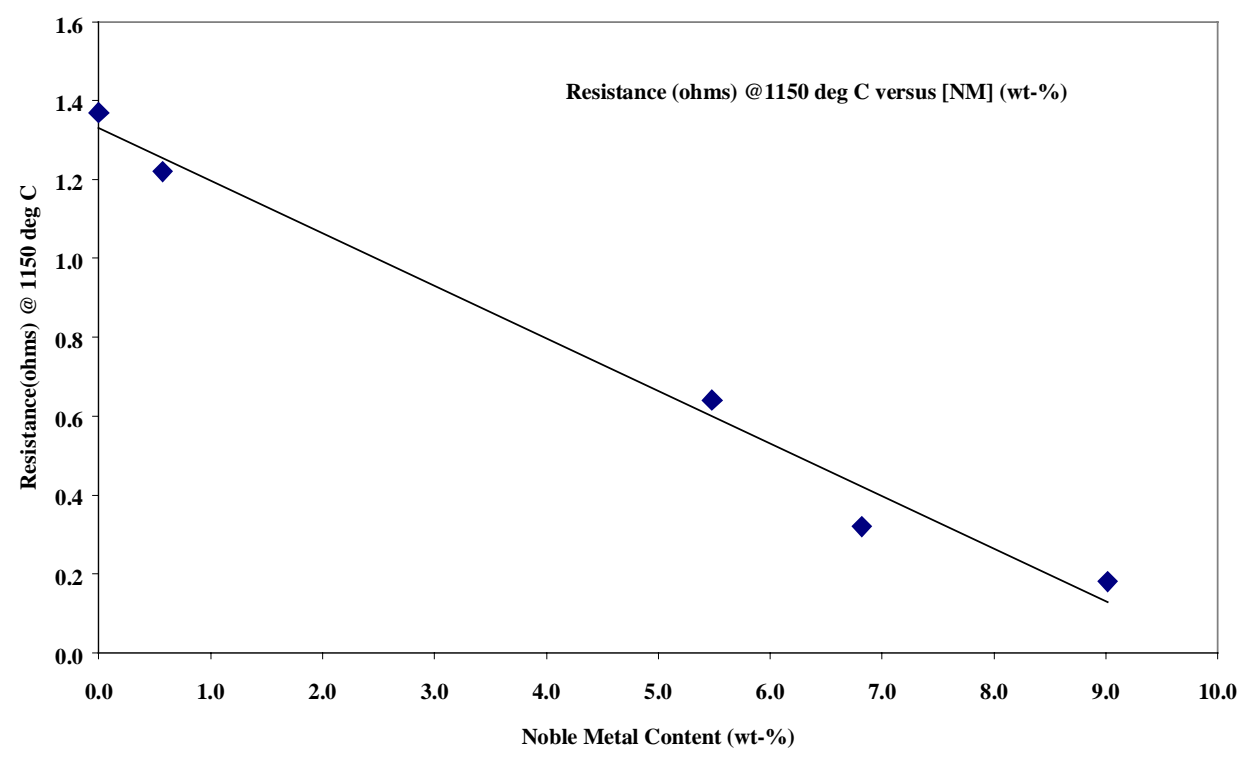

Figure 4-4. Relationship between Noble Metal Content ([NM], wt-\%) and the Measured Resistance (ohms) at $1150{ }^{\circ} \mathrm{C}$ for IDMS Melter Floor (BLOB) Samples 


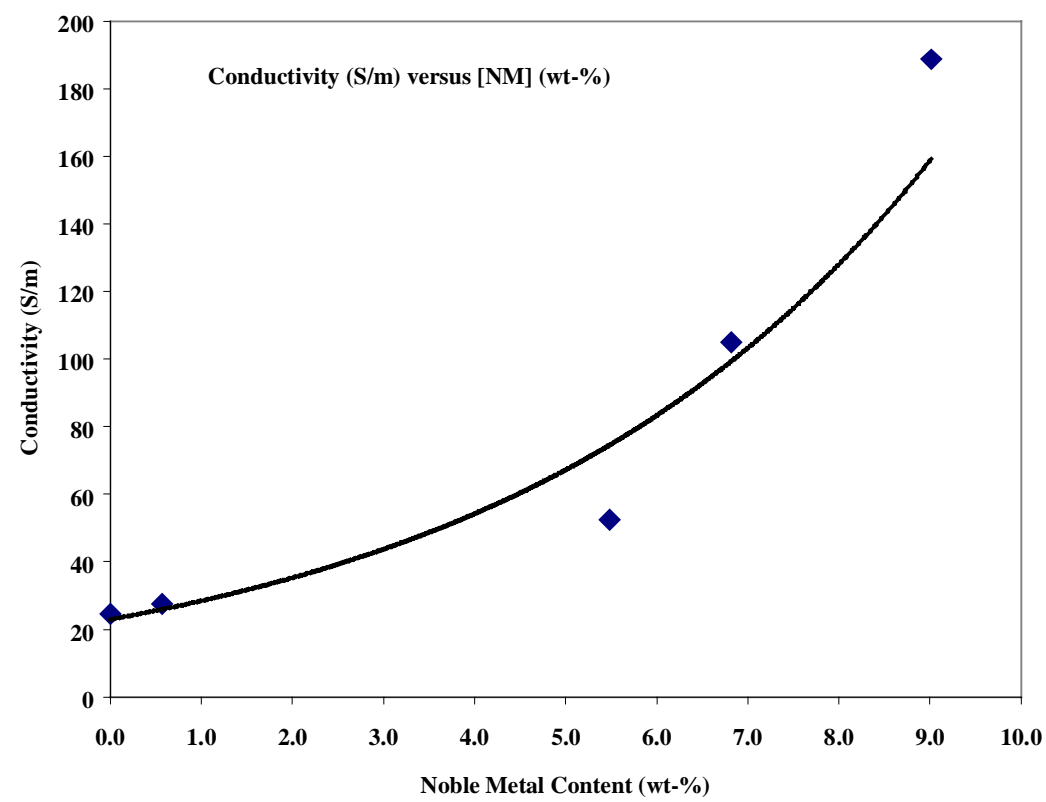

Figure 4-5. Relationship between Noble Metal Content ([NM], wt-\%) and the Measured Conductivity (S/m) at $1150{ }^{\circ} \mathrm{C}$ for IDMS Melter Floor (BLOB) Samples 


\subsection{Noble Metals Testing in the PNNL Engineering Scale Melter (ESM)}

The Engineering Scale Melter (ESM) is a $1 / 10^{\text {th }}$-scale melter (Note: The Hanford Waste Vitrification Plant, HWVP, was being designed to use the DWPF melter). The ESM was constructed and operated by personnel at the Institute für Nuklear Entsorgungstechnik at Kernforshungzentrum Karlsruhe (INE/KfK) in Karlsruhe, Germany (Grunewald et al., 1993a, 1993b) under a contract with PNNL. The ESM testing was conducted in the summer of 1992 to evaluate noble metals behavior during prolonged melter operation at the projected levels of the proposed Hanford vitrification plant. The overall objective of the ESM test was to operate the melter under anticipated HWVP process conditions over sufficient run time to determine if the noble metals accumulate in the melter as a function of time and feeding conditions. The ESM operated for 9 days without noble metals for shakedown testing and for 49 days with noble metals. The final mass balance concluded that $35 \mathrm{wt}-\%$ of the ruthenium, rhodium and palladium fed to the melter settled to the melter floor. Samples taken from the bottom of the melter at the end of the run had high concentrations of noble metals, some 20 to 45 times higher than those of the nominal glass. Near the end of the run, the electrical resistance between the lower set of electrodes decreased by $10-15 \%$, further indicating a settled layer of noble metals (Sundaram and Perez, 2000).

The ESM was eventually moved to the Clemson Environmental Technologies Laboratory (CETL) at Clemson University (Anderson, South Carolina). The melter had already been drained; however, it still contained a thin ( $<0.5$-in) layer of glassy material on the melter floor. This material was sampled on 3/29/01 at the CETL facility.

Figure 5-1 shows an overhead schematic of the melter with the sample locations shown as numbers on the schematic.

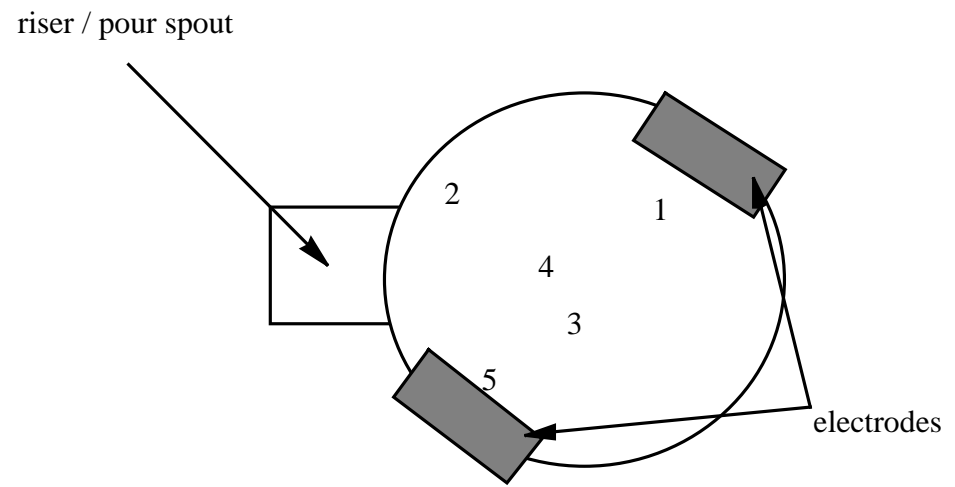

Figure 5-1. Overhead Schematic of the Engineering Scale Melter (ESM).

(Note: The numbers indicate melter floor sampling locations.) 
The samples were shipped, along with some archived IDMS samples (as described earlier), to the Pacific Northwest National Laboratory for characterization. The quantity of the ESM samples was insufficient for measurement of high temperature conductivity. However, chemical characterization was done (though Ru was the only one of the noble metals measured) and SEM/EDX analysis was also done. The results of the chemical characterization are given in Table 5-1. As with the IDMS floor samples, the ESM samples suggest a non-uniform ([Ru] varied from 2.20 to $7.44 \mathrm{wt}-\%)$ accumulation of noble metals and spinel components ( $\mathrm{Ni}, \mathrm{Cr}, \mathrm{Fe}$, and $\mathrm{Zr}$ ). The samples were all very high in chromium (see Table 5-1). Although, based on the IDMS results, it seems likely that there is some accumulation of $\mathrm{Cr}$-containing spinels, the primary source of $\mathrm{Cr}$ in these samples is likely from the Monofrax ${ }^{\mathrm{TM}} \mathrm{K}-3$ refractory. Since the glassy floor material was so thin, it was nearly impossible to remove just that layer with no contamination from the refractory. The samples showed a significant enrichment of $\mathrm{Ru}$ as compared to the target NCAW'91 glass composition (Hutson, 1993a). The samples nearest to the electrodes (\#1 and \#5) had the lowest composition of spinel components ( $\mathrm{Ni}, \mathrm{Fe}, \mathrm{Cr}, \mathrm{Zr}$ ) and the highest composition of $\mathrm{Ru}$. In fact, the Ni values were near that of the NCAW glass target and the Fe values were below the target. The $\mathrm{Zr}$ is only slightly enriched in these samples. The sample taken at the outside edge furthest from the electrodes (\#2) had the highest concentration of the spinel components and the lowest concentration of Ru (although there was still a significant enrichment over the target Ru concentration). The disparity in the concentration of various components are likely due to a combination of uneven convection currents in the melter and to temperature differences within the melter (cooler regions would tend to be higher in spinel components).

Table 5-1. Selected Components in Floor Samples from the Engineering Scale Melter (ESM)

\begin{tabular}{cccccc}
\hline $\begin{array}{c}\text { Sample } \\
\text { Location }\end{array}$ & $\begin{array}{c}\text { Ru } \\
\text { wt-\% }\end{array}$ & $\begin{array}{c}\text { Ni } \\
\text { wt-\% }\end{array}$ & $\begin{array}{c}\mathbf{C r} \\
\text { wt-\% }\end{array}$ & $\begin{array}{c}\mathbf{F e} \\
\text { wt-\% }\end{array}$ & $\begin{array}{c}\mathbf{Z r} \\
\text { wt-\% }\end{array}$ \\
\hline 1 & 5.65 & 0.83 & 2.55 & 3.97 & 4.04 \\
2 & 2.20 & 2.70 & 5.00 & 6.92 & 4.86 \\
3 & 3.96 & 1.15 & 2.51 & 4.14 & 4.94 \\
4 & 4.51 & 1.46 & 3.56 & 4.30 & 4.39 \\
5 & 7.44 & 0.55 & 1.15 & 3.46 & 4.11 \\
Target* & 0.09 & 0.52 & 0.06 & 5.68 & 3.19 \\
\hline * Target in NCAW'91 glass (Hutson, 1993a) & &
\end{tabular}




\subsection{West Valley Demonstration Project Operating Experience}

At the West Valley Demonstration Project (WVDP), the slurry-fed ceramic melter (SFCM) was designed prior to the sloped bottom German and Japanese melters. It has a unique prismoidal shape with sloping walls and a bottom electrode that was intended to minimize noble metals effects. The expected ruthenium concentration in WVDP radioactive glass was $0.08 \%$ by weight based on fuel burn-up fission product yields. Analyses after start of radioactive operations indicate actual values of 0.06 to $0.15 \%$. The expected concentration is very similar to DWPF glass if made from HM sludge (see Table 2-1).

The SCFM was in test operation from December 1984 to December 1989 to vitrify simulated nuclear waste slurries (Jain et al., 1991). In that study, deposits of melt insolubles and crystallized species that accumulated on the SFCM floor during the vitrification process were analyzed. The results indicated that the thickness of the sludge layer on the floor of the SFCM was not more than 6-cm deep and consisted mostly of $\mathrm{Fe}-\mathrm{Cr}$ spinels, and $\mathrm{RuO}_{2}$ dispersed in a glassy borosilicate matrix. Also, crystalline $\mathrm{Ce}_{2} \mathrm{O}_{3}$ and undissolved phases consisting primarily of alumina and chromia were present in trace amounts but were inhomogeneously distributed in the glassy matrix on the SFCM floor. Greater than $87 \%$ of the $\mathrm{RuO}_{2}$ fed to the melter was flushed out with normal glass pouring.

Five days of non-radioactive surrogate operations with noble metals were conducted on the WVDP melter before radioactive operations were started. No electrical disturbances were noted during the short test period, but deposits were found on the melter bottom and at the dihedral angle between melter walls, analogous to the German W-4 campaign experience. A preliminary material balance showed that $95 \%$ of the Ru had been washed out via the overflow drain.

The WVDP began radioactive operations in 1996, and after approximately one year of operation, in the fall of 1997, a dramatic change in the electrical resistance of the melter was noted. This required adjustment to current control limits to the melter. Long term trending of historical data from the WVDP melter indicated a downward trend in the electrical resistance between the melter electrodes and skewing of current toward the bottom electrode. The problem was significant enough that a team of vitrification experts was assembled. Preliminary conclusions from that team were as follows.

- Deposits of noble metals most likely caused the downward trend in electrical resistance and the skewing of current towards the bottom electrode.

- The primary effect caused by the accumulation of noble metals was that more current was required to maintain the same power input into the melter.

- Trending indicated that sufficient current capacity was available to maintain the desired glass production rate in the short term. 
The assembled team of vitrification experts gave numerous recommendations for addressing the WVDP noble metals concerns in 1997. The team recommended that WVDP should:

- assess the adequacy of currently available diagnostic/monitoring capabilities for detecting accumulation of noble metals;

- develop enhanced melter monitoring and detection capabilities with appropriate action limits;

- $\quad$ predict future melter power needs and develop "work arounds" to meet these needs;

- continue to collect and evaluate data aimed at characterizing the noble metal deposits in the melter;

- develop tools to dislodge the deposits of noble metals in situ;

- develop methods for flushing and draining the melter to remove deposits; and

- develop methods for visually inspecting the melter if it is drained and mechanically dislodging the deposits.

The response of the West Valley melter to the slow accumulation of noble metals has been successfully modeled using a "corner model". This is described in another report (Sundaram and Perez, 2000). The electrical response of the West Valley melter, after gradually declining, remained fairly constant and operation continued. The tank waste has currently been completely fed and the facility is processing tank residue and heels. A sample of the melter floor material has been taken and complete characterization is in progress. During sampling, it was noted that there was a highly viscous layer > 2" present on the melter floor (Palmer, 2001). 


\subsection{DWPF Operation}

\subsection{Operational Experiences to Date}

The DWPF melter has been in radioactive operation since 1996. The facility is nearing completion of Tank 51 sludge 1B (macrobatch 2). Some historical data seem to indicate that the melter is now displaying symptoms that may be linked to accumulation of noble metals or other conductive material on the melter floor. During the time period from July 2000 to December 2000, the monthly average ratio of upper-to-lower melt apparent resistance increased from 1.02 to 1.60. The ratio has stayed between 1.30 and 1.60 during all of 2001 (Note: This data was last updated for this report on July 12, 2001). This is shown in Figure 7-1.

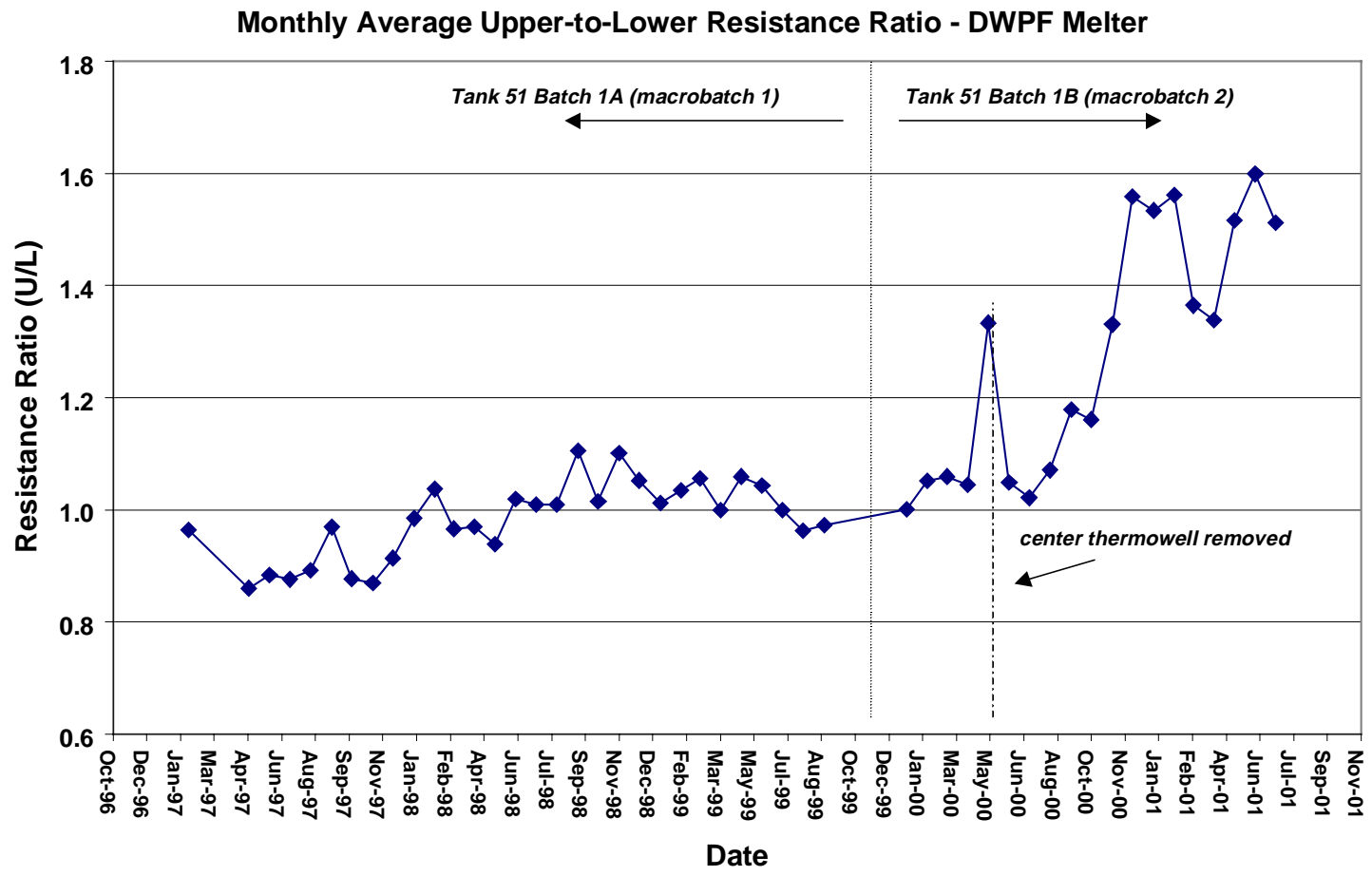

Figure 7-1. Monthly Average Upper-to-Lower Resistance Ratio - DWPF Meler

There are operational changes, however, that must be considered in evaluating this data. In November 1999, a new sludge macrobatch (Tank 51 sludge 1B, macrobatch 2) was introduced. This sludge was higher in aluminum than the previous macrobatch had been. This resulted in a more viscous molten glass and possibly less convection in the melter. Also, in May 2000 a thermowell with three thermocouples was removed from the center of the melter (measuring the lower glass pool temperature). The average lower glass pool temperature abruptly dropped at that time since it was then the average of only three thermocouple readings in a thermowell located near the outer edge of the melter wall (a colder region of the melt pool). So, the change in the resistance ratio is, at least partially, due to this artificial drop in the lower glass temperature (and a corresponding increase in the upper glass temperature). Prior to May 2000, the average lower glass pool temperature, which at that time was an average of six thermocouple 
readings (three in the center of the melter and three at the outer edge of the melt pool), consistently ran from 1100 to $1120^{\circ} \mathrm{C}$. The average upper glass pool temperature was typically between 1140 and $1170{ }^{\circ} \mathrm{C}$. However, after May 2000, the monthly average temperature (of just the three outer edge thermocouple readings) for the lower glass pool has ranged from 1060 to $1080{ }^{\circ} \mathrm{C}$. Average monthly upper and lower glass pool resistances are shown in Figure 7-2. Average monthly upper and lower glass pool temperatures are shown in Figure 7-3.

In the early periods of radioactive operation, the amount of current supplied to the upper set of electrodes was typically nearly the same or slightly more than that supplied to the lower set (sometimes as much as $25 \%$ more). In June 2000 the amount of current supplied to the respective electrodes began to diverge, increasing from 916 to 1226 amps for the lower electrodes and decreasing from 923 to 729 amps for the upper electrodes (monthly averages between June 2000 and July 2001). This is shown in Figure 7-4. The ratio of upper-to-lower electrode current is shown in Figure 7-5. There has been a consistent downward trend in this measure. The lower electrodes are now provided with approximately $40 \%$ more current than that provided to the upper electrodes. The data for all of these figures (Figures 7-1 through 7-5) are provided in Table 7-1.

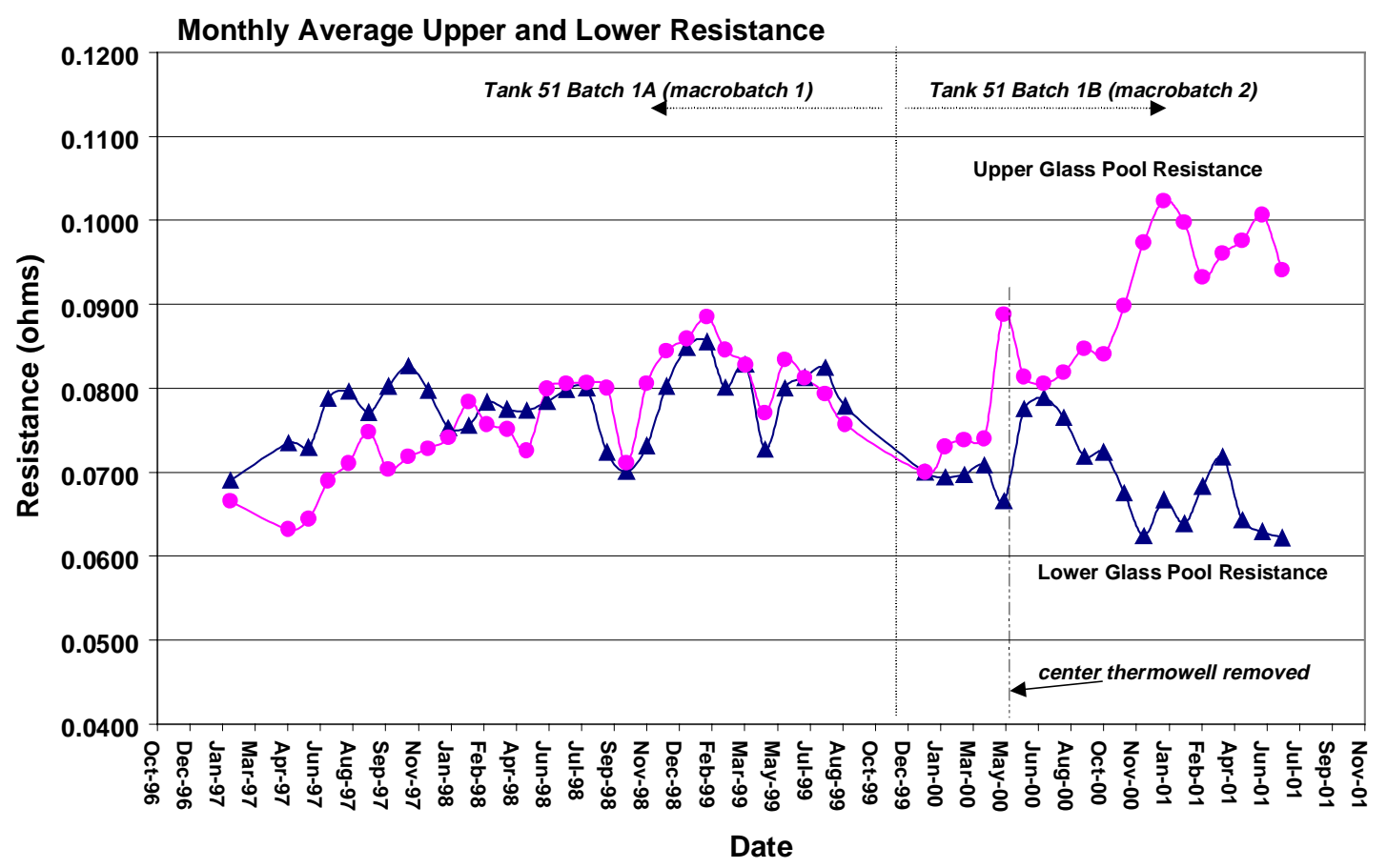

Figure 7-2. Monthly Average Upper and Lower Glass Pool Resistances 


\section{Average Upper and Lower Glass Pool Temps (deg C)}

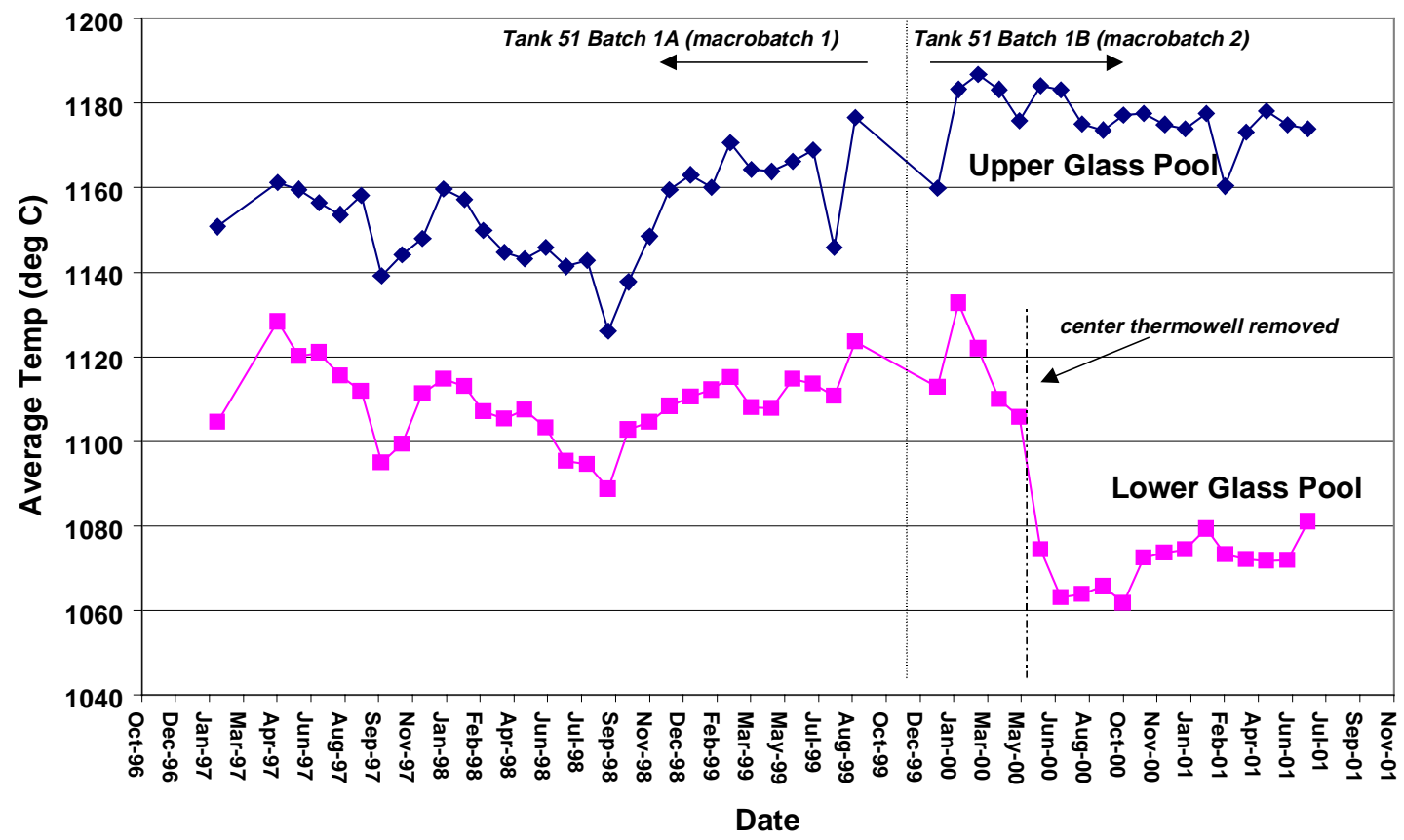

Figure 7-3. Monthly Average Upper and Lower Glass Pool Temperature

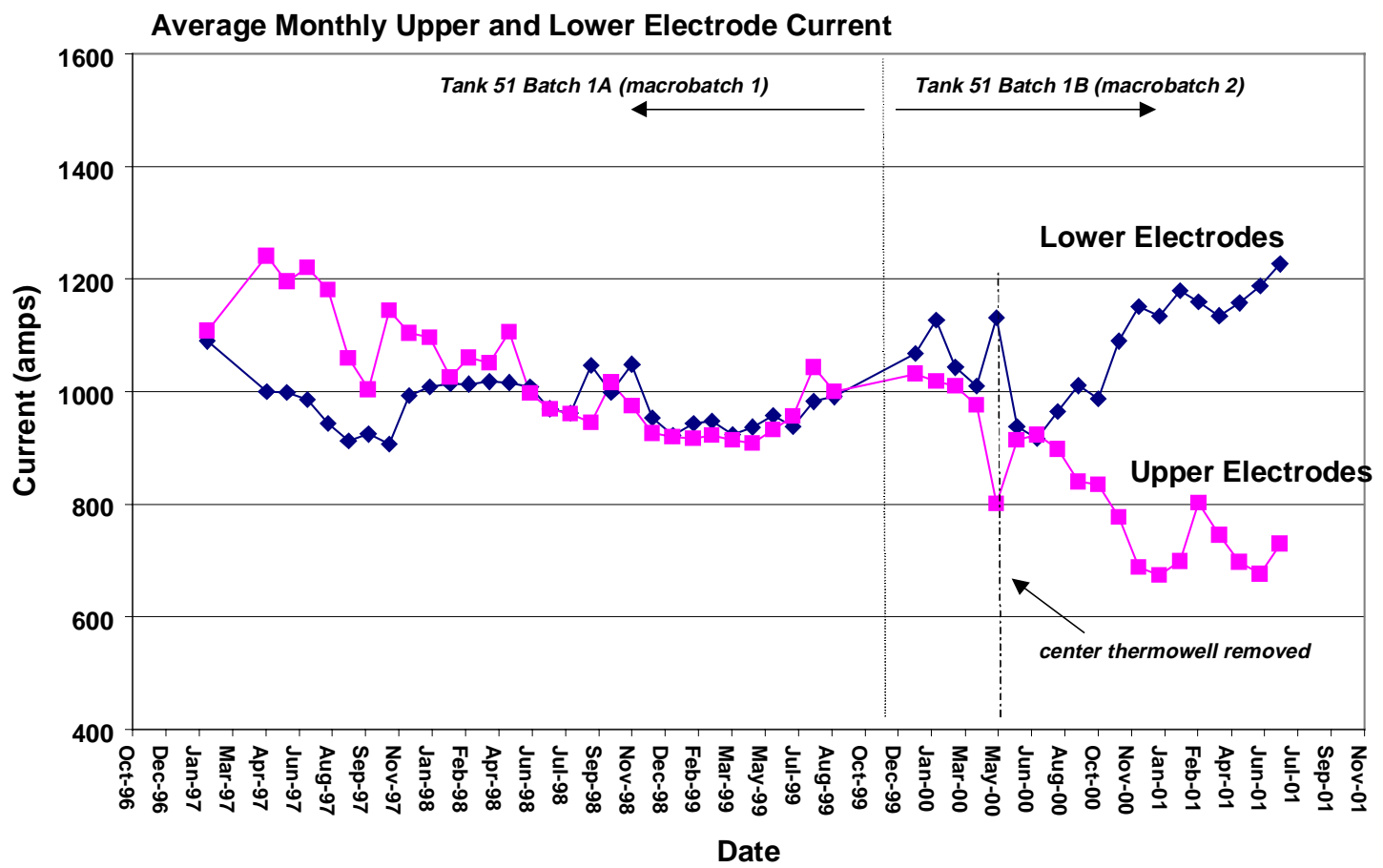

Figure 7-4. Monthly Average Upper and Lower Electrode Current (amps) 


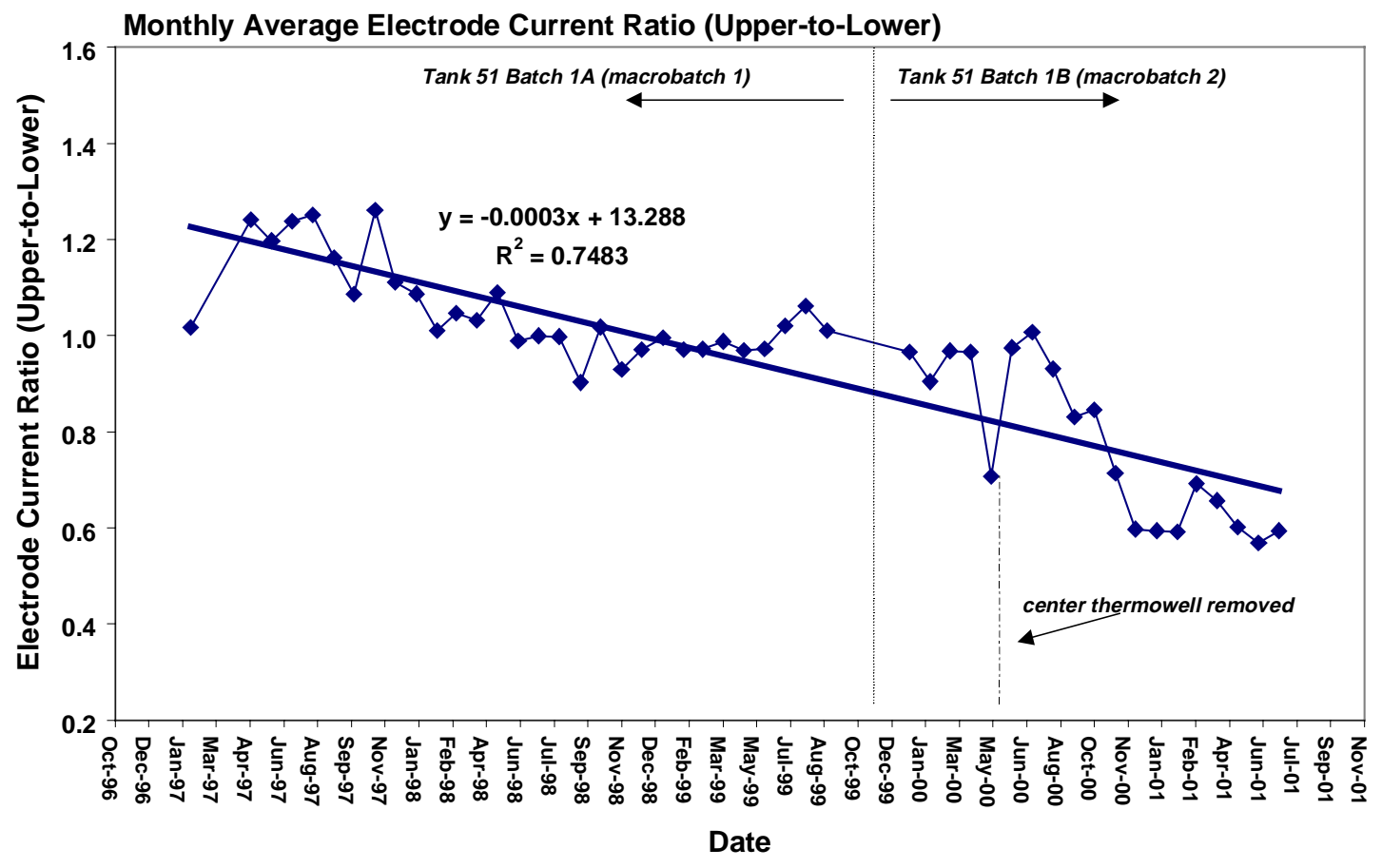

Figure 7-5. Monthly Average Electrode Current Ratio (Upper-to-Lower)

All of these events are consistent with observations made during the operation of the IDMS melter. Similar to that observed in the DWPF, the resistance ratio for the IDMS melter was initially stable, oscillating from 1.1 to 1.3. However, after 550 days of operation with noble metals the resistance ratio increased dramatically and continued upward, over time, to $2.3-2.5$. The sudden increase in the resistance ratio corresponded to a time when melter floor samples revealed a significant increase in the amount of material on the melter floor. Upon close examination of the date (plots are presented in Smith and Bickford, 1997), it appears that the IDMS upper-to-lower resistance ratio increased largely because of an increase in the apparent resistance in the upper glass pool. The lower glass pool resistance did have a gradual drop during a 100-day period of operation (during days 500 to 600 of operation) when the lower glass pool resistance declined from the nominal $0.10 \mathrm{ohms}$ to about $0.06 \mathrm{ohms}$. It remained at about 0.06 to $0.07 \mathrm{ohms}$ for the remainder of the operation. The upper glass pool resistance also declined during the same 100day period, from the initial 0.12 down to about 0.10 . It then decreased to about 0.08 before beginning a steady increase up to approximately $0.15 \mathrm{ohms}$. In contrast, the DWPF melter has not had a sustained decrease in the lower melt pool resistance.

Eventually, due to the accumulation of conductive material, a lower electrode current density of approximately 6.1 amps $/ \mathrm{in}^{2}$ (compared to the design value of $5.0 \mathrm{amps} / \mathrm{in}^{2}$ ) was required to maintain the lower glass pool at $1070^{\circ} \mathrm{C}$. 
The DWPF lower electrode current density is now below $3.0 \mathrm{amps} / \mathrm{in}^{2}$ and has not exceeded the design value (although non-uniform firing can lead to localized areas of high current density). 
Table 7-1. Monthly Average Operational Parameters for the DWPF Melter

\begin{tabular}{|c|c|c|c|c|c|c|c|c|c|}
\hline \multirow[t]{2}{*}{ Date } & \multicolumn{3}{|c|}{ Resistance } & \multicolumn{3}{|c|}{ Glass Pool Temperature } & \multicolumn{3}{|c|}{ Electrode Current } \\
\hline & $\begin{array}{c}\text { Lower } \\
\text { Ohms }\end{array}$ & $\begin{array}{l}\text { Upper } \\
\text { Ohms }\end{array}$ & $\begin{array}{c}\text { Ratio } \\
\text { U/L }\end{array}$ & Upper & Lower & $\begin{array}{c}\text { Ratio } \\
\text { U/L }\end{array}$ & $\begin{array}{l}\text { Lower } \\
\text { Amps }\end{array}$ & $\begin{array}{c}\text { Upper } \\
\text { Amps }\end{array}$ & $\begin{array}{c}\text { Ratio } \\
\text { U/L }\end{array}$ \\
\hline Feb-97 & 0.0690 & 0.0665 & 0.964 & 1150.8 & 1104.6 & 1.042 & 1089.70 & 1107.94 & 1.017 \\
\hline May-97 & 0.0735 & 0.0632 & 0.860 & 1161.3 & 1128.3 & 1.029 & 999.88 & 1241.00 & 1.241 \\
\hline Jun-97 & 0.0729 & 0.0645 & 0.884 & 1159.6 & 1120.2 & 1.035 & 998.27 & 1195.41 & 1.197 \\
\hline Jul-97 & 0.0788 & 0.0690 & 0.876 & 1156.4 & 1121.0 & 1.032 & 986.20 & 1220.46 & 1.238 \\
\hline Aug-97 & 0.0796 & 0.0711 & 0.892 & 1153.6 & 1115.5 & 1.034 & 943.74 & 1180.70 & 1.251 \\
\hline Sep-97 & 0.0771 & 0.0748 & 0.969 & 1158.2 & 1111.8 & 1.042 & 912.25 & 1059.92 & 1.162 \\
\hline Oct-97 & 0.0802 & 0.0704 & 0.877 & 1139.1 & 1095.0 & 1.040 & 924.35 & 1003.74 & 1.086 \\
\hline Nov-97 & 0.0826 & 0.0719 & 0.870 & 1144.1 & 1099.4 & 1.041 & 906.65 & 1143.85 & 1.262 \\
\hline Dec-97 & 0.0797 & 0.0728 & 0.914 & 1148.0 & 1111.3 & 1.033 & 993.46 & 1103.91 & 1.111 \\
\hline Jan-98 & 0.0753 & 0.0741 & 0.985 & 1159.6 & 1114.7 & 1.040 & 1008.47 & 1096.04 & 1.087 \\
\hline Feb-98 & 0.0756 & 0.0784 & 1.037 & 1157.2 & 1113.0 & 1.040 & 1014.92 & 1026.04 & 1.011 \\
\hline Mar-98 & 0.0783 & 0.0757 & 0.966 & 1149.9 & 1107.1 & 1.039 & 1013.31 & 1060.44 & 1.047 \\
\hline Apr-98 & 0.0775 & 0.0751 & 0.970 & 1144.7 & 1105.3 & 1.036 & 1017.70 & 1050.71 & 1.032 \\
\hline May-98 & 0.0773 & 0.0726 & 0.939 & 1143.1 & 1107.4 & 1.032 & 1015.94 & 1106.42 & 1.089 \\
\hline Jun-98 & 0.0785 & 0.0799 & 1.019 & 1145.9 & 1103.3 & 1.039 & 1008.33 & 996.79 & 0.989 \\
\hline Jul-98 & 0.0798 & 0.0806 & 1.009 & 1141.4 & 1095.3 & 1.042 & 969.75 & 969.26 & 0.999 \\
\hline Aug-98 & 0.0800 & 0.0807 & 1.009 & 1142.8 & 1094.5 & 1.044 & 962.12 & 960.28 & 0.998 \\
\hline Sep-98 & 0.0724 & 0.0801 & 1.106 & 1126.1 & 1088.7 & 1.034 & 1046.31 & 944.57 & 0.903 \\
\hline Oct-98 & 0.0701 & 0.0711 & 1.015 & 1137.7 & 1102.8 & 1.032 & 998.47 & 1015.98 & 1.018 \\
\hline Nov-98 & 0.0732 & 0.0805 & 1.101 & 1148.4 & 1104.6 & 1.040 & 1048.55 & 974.85 & 0.930 \\
\hline Dec-98 & 0.0802 & 0.0844 & 1.052 & 1159.5 & 1108.3 & 1.046 & 953.32 & 926.03 & 0.971 \\
\hline Jan-99 & 0.0849 & 0.0859 & 1.013 & 1163.0 & 1110.5 & 1.047 & 922.88 & 919.08 & 0.996 \\
\hline Feb-99 & 0.0855 & 0.0885 & 1.035 & 1160.1 & 1112.2 & 1.043 & 943.72 & 916.53 & 0.971 \\
\hline Mar-99 & 0.0801 & 0.0846 & 1.056 & 1170.7 & 1115.1 & 1.050 & 948.37 & 921.84 & 0.972 \\
\hline Apr-99 & 0.0828 & 0.0828 & 1.000 & 1164.3 & 1108.0 & 1.051 & 924.06 & 913.20 & 0.988 \\
\hline May-99 & 0.0727 & 0.0770 & 1.059 & 1163.8 & 1107.8 & 1.051 & 936.90 & 908.38 & 0.970 \\
\hline Jun-99 & 0.0800 & 0.0834 & 1.043 & 1166.2 & 1114.8 & 1.046 & 958.23 & 932.09 & 0.973 \\
\hline Jul-99 & 0.0813 & 0.0812 & 0.999 & 1168.9 & 1113.6 & 1.050 & 937.97 & 956.71 & 1.020 \\
\hline Aug-99 & 0.0824 & 0.0793 & 0.962 & 1145.9 & 1110.8 & 1.032 & 982.61 & 1043.44 & 1.062 \\
\hline Sep-99 & 0.0779 & 0.0757 & 0.972 & 1176.6 & 1123.5 & 1.047 & 991.01 & 1000.67 & 1.010 \\
\hline Jan-00 & 0.0700 & 0.0700 & 1.000 & 1159.8 & 1112.9 & 1.042 & 1067.50 & 1031.58 & 0.966 \\
\hline Feb-00 & 0.0694 & 0.0730 & 1.052 & 1183.2 & 1132.7 & 1.045 & 1126.69 & 1018.95 & 0.904 \\
\hline Mar-00 & 0.0697 & 0.0738 & 1.059 & 1186.9 & 1122.0 & 1.058 & 1043.24 & 1010.26 & 0.968 \\
\hline Apr-00 & 0.0708 & 0.0740 & 1.045 & 1183.2 & 1110.0 & 1.066 & 1010.11 & 976.16 & 0.966 \\
\hline May-00 & 0.0666 & 0.0888 & 1.334 & 1175.8 & 1105.7 & 1.063 & 1131.53 & 800.47 & 0.707 \\
\hline Jun-00 & 0.0776 & 0.0814 & 1.049 & 1184.1 & 1074.5 & 1.102 & 937.33 & 913.75 & 0.975 \\
\hline Jul-00 & 0.0789 & 0.0806 & 1.021 & 1183.1 & 1063.1 & 1.113 & 916.84 & 923.03 & 1.007 \\
\hline Aug-00 & 0.0765 & 0.0819 & 1.071 & 1175.1 & 1063.8 & 1.105 & 964.15 & 897.55 & 0.931 \\
\hline Sep-00 & 0.0719 & 0.0847 & 1.179 & 1173.6 & 1065.7 & 1.101 & 1010.87 & 839.53 & 0.830 \\
\hline Oct-00 & 0.0724 & 0.0841 & 1.161 & 1177.1 & 1061.8 & 1.109 & 986.91 & 834.61 & 0.846 \\
\hline Nov-00 & 0.0675 & 0.0898 & 1.331 & 1177.5 & 1072.4 & 1.098 & 1089.70 & 777.30 & 0.713 \\
\hline Dec-00 & 0.0624 & 0.0973 & 1.559 & 1174.9 & 1073.7 & 1.094 & 1151.40 & 687.57 & 0.597 \\
\hline Jan-01 & 0.0667 & 0.1023 & 1.534 & 1173.9 & 1074.4 & 1.093 & 1133.77 & 673.89 & 0.594 \\
\hline Feb-01 & 0.0639 & 0.0998 & 1.562 & 1177.6 & 1079.3 & 1.091 & 1179.60 & 698.72 & 0.592 \\
\hline Mar-01 & 0.0683 & 0.0932 & 1.365 & 1160.4 & 1073.2 & 1.081 & 1159.80 & 802.07 & 0.692 \\
\hline Apr-01 & 0.0718 & 0.0961 & 1.338 & 1173.2 & 1072.2 & 1.094 & 1134.76 & 745.28 & 0.657 \\
\hline May-01 & 0.0643 & 0.0976 & 1.517 & 1178.1 & 1071.8 & 1.099 & 1157.68 & 696.76 & 0.602 \\
\hline Jun-01 & 0.0629 & 0.1006 & 1.599 & 1174.8 & 1071.9 & 1.096 & 1188.01 & 675.85 & 0.569 \\
\hline Jul-01 & 0.0622 & 0.0941 & 1.513 & 1173.9 & 1081.0 & 1.086 & 1226.63 & 729.26 & 0.595 \\
\hline
\end{tabular}




\subsection{Future Tank Wastes}

The DWPF has been in radioactive operation since 1996 and will soon begin feeding a new sludge with concentrations of noble metals that are higher than have been processed to date. Table 7-2 gives the predicted noble metal concentrations for HM, PUREX and Blend sludges (a hypothetical blending of PUREX and HM). Also listed are measured values for Tank 51-1A (sludge batch 1A, macrobatch 1) and for Tank 40, the next sludge batch to the DWPF. The values for Tank 40 represent the maximum (overwashed) and minimum (as received) bounding values for these components (Fellinger and Bibler, 2001). The values for Tank 40 indicate a significant increase in the expected values of $\mathrm{Ru}$ and $\mathrm{Rh}$ (the noble metals that tend to be retained in the melter in the highest percentages) over that of Tank 51-1A. The Rh concentration is 5 to 10 times higher in Tank 40 than in Tank 51-1A. (Note: The concentration of each depends on the degree of washing. The SRS sludge is washed to remove excess aluminum and sodium. The lower value represents the "no washing" extreme and the upper value represents the "overwashed" extreme).

Table 7-2. Predicted and Measured Noble Metal Concentrations in Various Savannah River Sludges

\begin{tabular}{ccccccc}
\hline & $\begin{array}{c}\text { Blend } \\
\text { Predicted } \\
\text { wt-\% }\end{array}$ & $\begin{array}{c}\text { HM } \\
\text { Predicted } \\
\text { wt-\% }\end{array}$ & $\begin{array}{c}\text { PUREX } \\
\text { Predicted } \\
\text { wt-\% }\end{array}$ & $\begin{array}{c}\text { Tank 51 } \\
\text { Measured } \\
\text { wt-\% }\end{array}$ & $\begin{array}{c}\text { Tank 40 Measured } \\
\text { (as received) } \\
\text { wt-\% }\end{array}$ & $\begin{array}{c}\text { (overwashed) } \\
\text { wt-\% }\end{array}$ \\
\hline $\mathrm{Ru}$ & 0.100 & 0.217 & 0.028 & 0.007 & 0.019 & 0.042 \\
$\mathrm{Rh}$ & 0.018 & 0.038 & 0.008 & 0.001 & 0.005 & 0.010 \\
$\mathrm{Pd}$ & 0.045 & 0.079 & 0.026 & 0.006 & 0.001 & 0.001 \\
$\mathrm{Ag}$ & 0.014 & 0.014 & 0.014 & 0.014 & 0.007 & 0.015 \\
\hline
\end{tabular}

(wt- $\%$ of the total sludge solids, soluble and insoluble)

The SRS Tank 51 sludge that has been fed to the DWPF melter has been very low in noble metals (concentration), much lower than was tested in the IDMS melter (see Table 1-1). The melter has experienced relatively few periods of extended idling. And now the DWPF is preparing to begin processing of a new batch of sludge that is much higher in noble metals. Most studies have indicated that the amount of noble metals that settle to the melter floor is greatly influenced by: 1) the concentration of the noble metals in the melt, 2) the size, shape and chemical state of the noble metals, and 3) the amount of mixing in the melter. The next sludge batch, from SRS Tank 40, is 2.7 to 6 times higher in Ru than that of Tank 51-1A (Tank 51 sludge 1A, macrobatch 1). The Rh concentration is 5 to 10 times higher in Tank 40 than in Tank 51-1A. Note: The concentration of each depends on the degree of washing. The SRS sludge is washed to remove excess aluminum and sodium. The lower value represents the "no washing" extreme and the upper value represents the "overwashed" extreme. In Research Scale Melter (RSM) studies at PNNL, the results suggested that there was a significant nonlinear increase in the amount of noble metal compounds deposited on the melter floor. With a 2-fold increase in the nominal noble metal content of the NCAW melter feed simulant there was a corresponding 9-fold increase in the fraction settling to the RSM floor (Cooper et al., 1994). The NCAW noble metals content is much closer to that of the SRS HM sludge, which is much higher than will be processed from Tank 40. So, the amount of noble metals that settle from that glass melt may not be 9-fold over that 
from Tank 51-1A, but, it is likely that there will be some nonlinear increase in noble metals settling from Tank 40 melter feed over than from the Tank 51-1A melter feed. 


\subsection{References}

Bickford, D. F.; Jantzen, C. M.; "Devitrification of Defense Nuclear Waste Glasses: The Role of Melt Insolubles", Journal of Non-Crystalline Solids, 84, pp. 299-307 (1986).

Cooper, M. F.; et. al.; "Research-Scale Melter Test Report", USDOE Report PNL-9428, Battelle Pacific Northwest National Laboratory, Richland, WA (1994).

Fellinger, T. L.; Bibler, N. E.; "Results of a Laboratory Washing Study Using the March 2001 Tank 40 Radioactive Slurry Samples - Original Composition and Over-Washed Composition (U)”, Interoffice Memorandum SRT-GPD-2001-00059, Savannah River Technology Center, Aiken, SC (2001).

Gentilucci, J. A.; "Melter Draw Down During Idling”, Correspondence to Joseph F. Ortaldo, JAG-SRS-01-001, JAG Technical Services, Aiken, SC (2001).

Grunewald, W.; Roth, G.; Tobie, W.; Weisenburger, S.; "Progress Achieved in HLW Vitrification Techniques at INE", Proceedings of the 1993 International Conference on Nuclear Waste Management and Environmental Remediation, Prague, Czech Republic, The American Society of Mechanical Engineers, p. 113 - 128 (1993a).

Grunewald, W.; Roth, G.; Tobie, W.; Weisenburger, S.; Weiss, K.; "Vitrification of Noble Metals Containing NCAW-Simulant with an Engineering Scale Melter (ESM)", KfK-INE Campaign Report (Results of work performed under Contract No. 125818-A-A3 for Battelle Pacific Northwest National Laboratory), (1993b).

Hutson, N. D.; "DWPT Technical Task Plan - IDMS Noble Metals Studies", USDOE Report WSRC-TR-900209, Savannah River Technology Center, Aiken, SC (1990).

Hutson, N. D.; Zamecnik, J. R.; Smith, M. E.; Miller, D. H.; Ritter, J. A.; "Integrated DWPF Melter System Campaign Report: Mercury Operation", USDOE Report WSRC-TR-91-0363, Savannah River Technology Center, Aiken, SC (1991a).

Hutson, N. D.; Zamecnik, J. R.; Smith, M. E.; Miller, D. H.; Ritter, J. A.; "Integrated DWPF Melter System Campaign Report: The First Two Noble Metals Operations", USDOE Report WSRC-TR-91-0400, Savannah River Technology Center, Aiken, SC (1991b).

Hutson, N. D.; Zamecnik, J. R.; Ritter, J. A.; Carter, J. T.; "Pilot Scale Processing of Simulated Savannah River Site High Level Radioactive Waste", Proceeding of the 1991 Joint International Waste Management Conference, Volume 2, Seoul, Korea (American Society of Mechanical Engineers, 1991c). 
Hutson, N. D.; Smith, M. E.; "The Behavior and Effects of the Noble Metals in the DWPF Melter System", Proceedings of the Third International Conference on High Level Radioactive Waste Management, Volume 1, Las Vegas, NV (1992).

Hutson, N. D.; "Integrated DWPF Melter System (IDMS) Campaign Report: Hanford Waste Vitrification Plant Process Demonstration (U)", USDOE Report WSRC-TR-92-0403 (Rev 1), Savannah River Technology Center, Aiken, SC (1993a).

Hutson, N. D.; "The Behavior of the Platinum Group Metals in a Borosilicate Waste Glass and Their Effects on the Operation of a Joule-Heated Melter", Ceramic Transactions. Nuclear Waste Management V. The American Ceramic Society, Westerville, OH (1993b).

Jain, V.; Barnes, S. M.; Vethanayagam, T. K.; Pye, L. D.; "Noble Metal and Spinel Deposition on the Floor of the Joule-Heated Ceramic Melter", J. Amer. Ceram. Soc., Vol. 74, No. 7, pp. 1559 - 62 (1991).

Jantzen, C. M.; Lambert, D. P.; "Inspection and Analysis of the Integrated DWPF Melter System (IDMS) after Seven Years of Operation (U)", USDOE Report WSRC-RP-96-575, Savannah River Technology Center, Aiken, SC (1997).

Krause, C.; Luckscheiter, B.; "Properties and Behavior of the Platinum Group Metals in the Glass Resulting from the Vitrification of Simulated Nuclear Fuel Reprocessing Waste", Journal of the Materials Research Society, Vol. 6, No. 12 (1991).

Palmer, R. A.; Personal Communications with Ronald A. Palmer, West Valley Demonstration Project, West Valley, NY, May - July (2001).

Smith, M. E.; Hutson, N. D.; Miller, D. H.; Morrison, J.; Shah, H. B.; Shuford, J. A.; Glascock, J; Wurzinger, F. H.; Zamecnik, J. R.; "Checkout and Startup of the Integrated DWPF Melter System", USDOE Report WSRC-RP89-0321, Savannah River Technology Center, Aiken, SC (1989).

Smith, M. E.; Bickford, D. F.; "The Behavior and Effects of the Noble Metals in the DWPF Melter System", USDOE Report WSRC-TR-97-00370, Savannah River Technology Center, Aiken, SC (1997).

Sundaram, S. K.; Perez, J. M.; "Noble Metals and Spinel Settling in High Level Waste Glass Melters", USDOE Report PNNL-13347, Pacific Northwest National Laboratory, Richland, WA (2000). 
Zamecnik, J. R.; Hutson, N. D.; Smith, M. E.; Miller, D. H.; Ritter, J. A.; "Integrated DWPF Melter System Campaign Report: DWPF Cold Run Demonstration", USDOE Report WSRC-RP-93-0593, Savannah River Technology Center, Aiken, SC (1993). 